Mater et caput omnium ecclesiarum: visual strategies in the rivalry between San Giovanni in Laterano and San Pietro in Vaticano

\author{
Jäggi, Carola
}

DOI: https://doi.org/10.1017/9781108885096.015

Posted at the Zurich Open Repository and Archive, University of Zurich

ZORA URL: https://doi.org/10.5167/uzh-192465

Book Section

Published Version

Originally published at:

Jäggi, Carola (2020). Mater et caput omnium ecclesiarum: visual strategies in the rivalry between San Giovanni in Laterano and San Pietro in Vaticano. In: Bosman, Lex; Haynes, Ian P; Liverani, Paolo. The basilica of Saint John Lateran to 1600. Cambridge: Cambridge University Press, 294-317.

DOI: https://doi.org/10.1017/9781108885096.015 


\title{
15 MATER ET CAPUT OMNIUM ECCLESIARUM: Visual Strategies in the Rivalry between San Giovanni in Laterano and San Pietro in Vaticano
}

\author{
CAROLA JÄGGI
}

Dedicated to Sible de Blaauw, a bit too late for his sixty-fifth birthday

In October 2014 a conference was held in Mannheim on 'The Popes and the Unity of the Latin World'. The papers from this conference have recently been published under the title Die Päpste: Amt und Herrschaft in Antike, Mittelalter und Renaissance. ${ }^{1}$ The book cover shows the silhouette of Saint Peter's basilica combined with Arnolfo di Cambio's statue of Pope Boniface VIII as one of the most famous representatives of the medieval papacy. But why the dome of Saint Peter's? Why not San Giovanni in Laterano, which is still the cathedral of the bishop of Rome and therefore stricto sensu the head and mother of all the other churches in Rome and the world? The honorary title OMNIVM VRBIS ET ORBIS ECCLESIARVM MATER ET CAPVT was officially assigned to the Lateran basilica by papal bull in 1372 and can be read still today in an inscription on the eighteenth-century façade of Alessandro Galilei (Fig. 15.1). ${ }^{2}$

The fact that the organisers of the Mannheim conference did not even comment on their choice of Saint Peter's basilica for the conference flyer and the book cover proves the close and unquestioned link between papacy and Saint Peter's in our perception today. The basilica of Saint Peter's actually seems to have turned into a cypher for the pope and for papacy as an institution. It is Saint Peter's that is regarded as the 'most important church in Western Christendom' and the 'most significant religious site in Western Europe', at least in the eyes of those colleagues who in March 2010 held a conference about

1 B. Schneidmüller, S. Weinfurter, M. Matheus and A. Wieczorek (eds.), Die Päpste: Amt und Herrschaft in Antike, Mittelalter und Renaissance (Regensburg, 2016).

2 For the bull of 1372 see Blaauw, CD I, 48; A. Rehberg, Die Kanoniker von S. Giovanni in Laterano und S. Maria Maggiore im 14. Jahrhundert (Tübingen, 1999), 21. For the history and evolution of the honorary title 'mater et caput omnium ecclesiarum' (and similar versions), see I. Herklotz, 'Der mittelalterliche Fassadenportikus der Lateranbasilika und seine Mosaiken. Kunst und Propaganda am Ende des 12. Jahrhunderts', RJBH 25 (1989), 27-95, at pp. 89-92; Blaauw, CD I, 204. For the eighteenth-century façade of San Giovanni in Laterano, see L. Barroero, 'La basilica dal cinquecento ai nostri giorni', in C. Pietrangeli (ed.), San Giovanni in Laterano (Florence, 1990), 145-255, at pp. 167-71; H. Hyde Minor, The Culture of Architecture in Enlightenment Rome (University Park, PA, 2010), 31-58. 


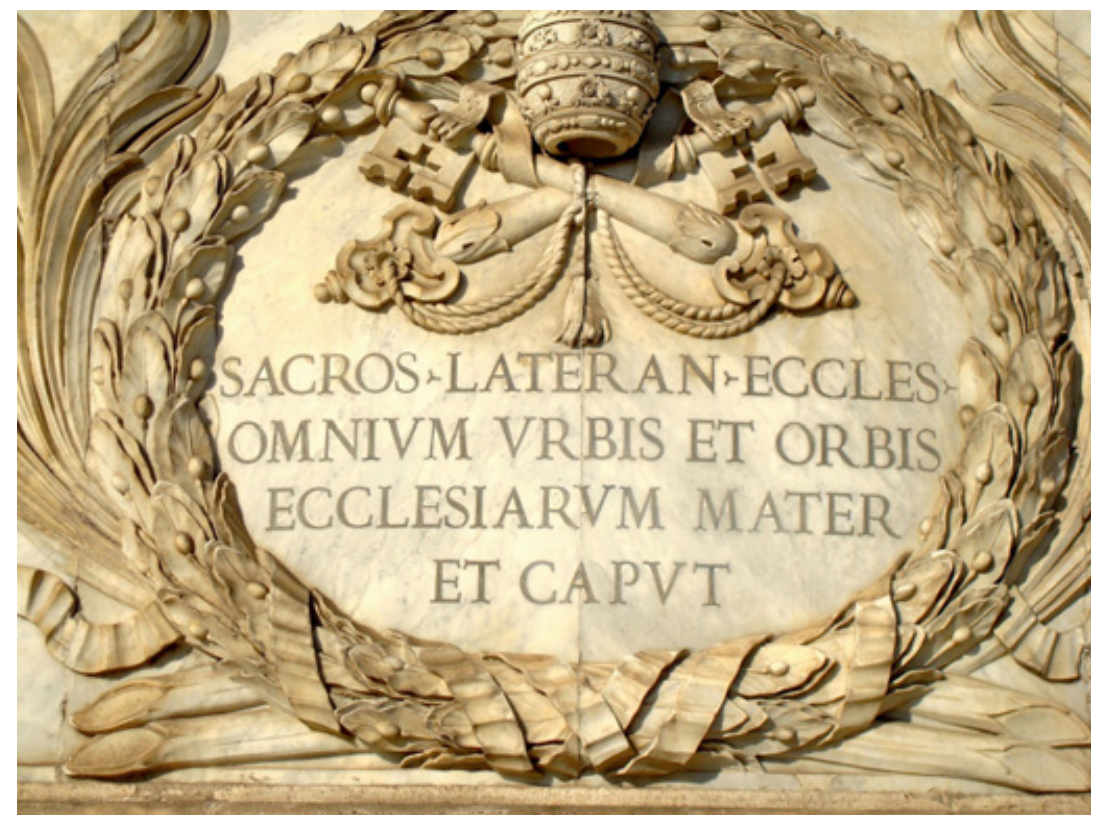

Fig. 15.1 Cartouche with inscription on the eighteenth-century façade of San Giovanni in Laterano (Photo: C. Jäggi).

Old Saint Peter's at the British School at Rome and therefore in the same location where six years later the Lateran conference took place. ${ }^{3}$ Even the sequence of these Roman conferences shows that the Lateran church is considered only second best. But so far nobody seems to have explicitly wondered why this is the case, nor when this process started, by whom it was prompted and which visual (and also non-visual) media were used. ${ }^{4}$

\section{The Lateran and Saint Peter's: Basic Commonalities and Differences}

We all know that the Lateran basilica was founded by Constantine immediately after the battle at the Milvian Bridge in $312 .{ }^{5}$ It was erected intra

3 R. McKitterick, J. Osborne, C. M. Richardson and J. Story, 'Introduction', in R. McKitterick, J. Osborne, C. M. Richardson and J. Story (eds.), Old Saint Peter's, Rome (British School at Rome Monograph Series) (Cambridge, 2013) 1-20 (quotations from pp. 1 and 7).

4 The topic will be discussed in greater detail by Angela Yorck von Wartenburg in her Ph.D. thesis.

5 For the early history of the Lateran see CBCR V, 10-11 and 25-48; Blaauw, CD I, 109-47; S. de Blaauw, 'Le origini e gli inizi dell'architettura cristiana', in S. de Blaauw (ed.), Storia dell'architettura italiana, vol. I: Da Costantino a Carlo Magno (Milan, 2010), 22-53, esp. pp. 32-5; P. C. Claussen, 'S. Giovanni in Laterano', in P. C. Claussen, Die Kirchen der Stadt Rom im Mittelalter, 1050-1300, 
muros, close to the city walls on the site of the former barracks of the equites singulares. It is equally known that the new church at the Lateran was consecrated to Christ the Saviour and given to the bishop of Rome as his cathedral. Saint Peter's basilica at the Vatican, however - and this again is a well-known fact - was also commissioned by Constantine, a few years later, and was destined to preserve the memoria for Saint Peter. ${ }^{6}$ With the basilica on the Vatican hill, the tomb of the prince of the apostles received a gigantic shrine destined to house additional tombs, funeral repasts and memorial services. The two churches were therefore built with completely different functions and different liturgical purposes: on the one hand there was the Saviour's church at the Lateran, where papal services were held, on the other hand there was Saint Peter's basilica at the Vatican, which was a kind of covered cemetery built around the memoria of Saint Peter.

It is evident that the situation today is a completely different one: Saint Peter's is now the pope's church for liturgical services, whereas in the Lateran basilica we find a number of sepulchral monuments. How did this reinterpretation happen? Why was a baptistery added to Saint Peter's in the fourth century (or in the fifth at the latest) while a spacious and richly decorated baptistery for papal baptismal services was available at the Lateran? What is the purpose of a baptistery at a memorial and pilgrimage church like Saint Peter's that - unlike other early Christian pilgrimage churches with proper baptisteries such as Qual'at Sem'an (in Syria) or Abu Mena (in Egypt) - does not lie remote from civilisation but next to a vibrant city with a magnificent cathedral-baptistery and a number of additional baptisteries in the urban titular churches? ${ }^{7}$ And - concerning the Lateran how could a pope even come up with the idea of choosing the intra-mural cathedral as his final resting place when, from the fifth century onwards, the traditional papal burial place had always been Saint Peter's? And how

Bd. 2: S. Giovanni in Laterano (Corpus Cosmatorum II, 2) (Forschungen zur Kunstgeschichte und Christlichen Archäologie 21) (Stuttgart, 2008), 25-8; B. M. Apollonj Ghetti, La basilica del Salvatore poi di S. Giovanni al Laterano cattedrale di Roma: Edizione a cura di Eugenio Russo (San Marino, 2013), 9-42. See also Bosman, Chapter 9 in this volume.

${ }^{6}$ CBCR V, 176-82 and 191-220; Blaauw, CD II, passim; de Blaauw, 'Le origini e gli inizi', 35-8; F. A. Bauer, 'Saint Peter's as a place of collective memory in Late Antiquity', in R. Behrwald and C. Witschel (eds.), Rom in der Spätantike: Historische Erinnerung im städtischen Raum (Stuttgart, 2012), 155-70. See also the respective contributions in McKitterick et al. (eds.), Old Saint Peter's, Rome.

${ }^{7}$ On the organisation of baptism in early Christian Rome, see B. Bruderer Eichberg, 'Prolegomena zur frühchristlichen und frühmittelalterlichen Tauforganisation in Rom: Die Baptisterien und die Stifterrolle der Päpste', in N. Bock, P. Kurmann, S. Romano and J.-M. Spieser (eds.), Art, cérémonial et liturgie au moyen age (Actes du Colloque de 3e Cycle Romand de Lettres, Lausanne/Fribourg 2000) (Rome, 2002), 321-56. 
was it that the Lateran, without containing the tomb of any saint, became the custodian of the holiest reliquary treasure of Rome, the Sancta Sanctorum, and as a consequence surpassed in holiness all the Roman churches that were built over the tombs of martyrs including Saint Peter's?

Questions such as these have rarely been asked with regard to the two main churches of Rome - perhaps because these two churches have hardly ever been compared directly. ${ }^{8}$ With such a comparative look at the Lateran and Saint Peter's, however, dynamics become apparent that provide insights into the ecclesiastical and worldly power structure of early Christian and medieval Rome.

\section{Foundation and Appropriation: Fourth-Ninth Centuries}

Let us start in the fourth century, when Constantine initiated and financed the new construction of the Roman episcopal church, and also founded the memorial church over the tomb of Saint Peter. I have already mentioned the fundamentally different functions and liturgical contexts of the two churches. This does not seem to have considerably changed until the fifth century: The Basilica Constantiniana at the Lateran was the papal celebration church, Saint Peter's a memorial and cemeterial basilica that soon became firmly established as the favourite burial place of the Christian upper class of Rome. In Saint Peter's, precious sarcophagi were erected or lowered into the floor, and on the exterior walls family mausoleums were built. In the early fifth century Saint Peter's even advanced to be the burial church of the western Roman emperors, as Honorius built a large mausoleum next to the south transept that followed the pattern of the Severan rotunda located immediately to the east. ${ }^{9}$ It is not only Honorius and his

\footnotetext{
8 Among the rare exceptions, above all Blaauw, CD I. See also M. Maccarone, 'L'indulgenza del Giubileo del 1300 e la basilica di San Pietro', in A. M. Romanini (ed.), Roma anno 1300: Atti della IV Settimana di Studi di Storia dell'Arte Medievale dell'Università di Roma La Sapienza (19-24 maggio 1980) (Rome 1983), 731-52, esp. 736-7; T. F. X. Noble, 'Topography, celebration and power: The making of papal Rome in the eighth and ninth centuries', in M. De Jong and F. Theuws (eds.), Topographies of Power in the Early Middle Ages (Leiden, 2001), 45-91, esp. 51-6; L. Bosman,

'S. Giovanni in Laterano and medieval architecture: The significance of architectural quotations', in M. Verhoeven, L. Bosman and H. van Asperen (eds.), Monuments and Memory: Christian Cult Buildings and Constructions of the Past: Essays in Honour of Sible de Blaauw (Architectural Crossroads. Studies in the History of Architecture 3) (Turnhout, 2016), 43-51, at pp. 43-4.

9 Blaauw, CD II, 466-8 (with reference to previous research); J. Niebaum, 'Die spätantiken Rotunden an Alt-St. Peter in Rom', Marburger Jahrbuch für Kunstwissenschaft 34 (2007), 101-61; M. J. Johnson, The Roman Imperial Mausoleum in Late Antiquity (Cambridge, 2009), 167-75; M. McEvoy, 'The mausoleum of Honorius: Late Roman imperial Christianity and the city of Rome in the fifth century', in McKitterick et al. (eds.), Old Saint Peter's, Rome, 119-36.
} 
two wives who appear to have been buried in this mausoleum, but also Galla Placidia, her first son Theodosius and even her second son Valentinian III, who died as emperor in 455.

But it seems as if the function of Saint Peter's had ceased to be merely funerary before the end of the fourth century with the construction of a baptistery under Pope Damasus (366-84); the details, however, are only poorly documented. ${ }^{10}$ Anyway, by the middle of the fifth century at the latest a baptistery must have existed at Saint Peter's as Pope Simplicius (468-83) established ebdomadas 'ad sanctum Petrum Apostolum', 'ut presbyteri manerent, propter penitentes et baptismum'. ${ }^{11}$ In the course of the fifth century Saint Peter's was apparently involved in papal stational service and in pastoral care for the residents of the suburbium. ${ }^{12}$ And yet, it was not turned into a 'normal' station church or into a titular church, but primarily became a highly political monument. ${ }^{13}$

The imperial character inherent in the building since its Constantinian foundation was reinforced by the construction of the imperial mausoleum by Honorius in the early fifth century, and also prevailed in the course of the following centuries. Consequently, it was Saint Peter's where emperors, kings and other rulers coming to Rome made their first stop. It was Saint Peter to whom they paid reverence in the first place, and it was his church where they were received by the pope and worldly dignitaries. ${ }^{14}$ This was the case with Honorius in 404, with Valentinian III in 425, with Theodoric

10 The construction of a baptistery in Saint Peter's by Pope Damasus is documented through inscriptions, but it is not attested in the Liber Pontificalis; for the documentary situation, see O. Brandt, 'The early Christian baptistery of Saint Peter's', in McKitterick et al. (eds.), Old Saint Peter's, Rome, 81-94, esp. 82-5. See also A. Ferrua, 'Dei primi battisteri Parocchiali e di quello di S. Pietro in particolare', La Civiltà Cattolica 90, 2 (1939), 146-57, at pp. 150-7; W. N. Schumacher, 'Das Baptisterium von Alt-St. Peter und seine Probleme', in O. Feld and U. Peschlow (eds.), Studien zur spätantiken und byzantinischen Kunst: F. W. Deichmann gewidmet, 3 vols. (Bonn, 1986), I, 215-33, at pp. 224-5; Blaauw, CD II, 487-8; H. Brandenburg, 'Das Baptisterium und der Brunnen des Atriums von Alt-St. Peter in Rom', BOREAS, Münstersche Beiträge zur Archäologie 26 (2003), 55-71, at pp. 56-7 and 64-5. On the role of the Damasian baptistery, see A. Thacker, 'Popes, emperors and clergy of Old Saint Peter's from the fourth to the eighth century', in McKitterick et al. (eds.), Old Saint Peter's, Rome, 137-56, at p. 145.

11 LP I, Life 49, 249 (c. 2); Thacker, 'Popes, emperors and clergy', 151.

12 For the development of the stational liturgy in early Christian Rome, see S. Diefenbach, Römische Erinnerungsräume: Heiligenmemoria und kollektive Identitäten im Rom des 3. bis 5. Jahrhunderts n. Chr. (Berlin, 2007), 232-3, 408-14 and 432.

13 See Blaauw, CD I, 27-31, 52-7 and II, 454-5, 484-5 and 498-503.

14 This was also for legal reasons, as Saint Peter's was positioned outside the city walls. Before entering the city, the foreign sovereigns had to ask the pope for permission to do so. In the case of Charlemagne's visit in 774, it is documented that the king of the Franks and his entourage had to leave the city every night and spend the night outside the city walls: S. Scholz, PolitikSelbstverständnis - Selbstdarstellung: Die Päpste in karolingischer und ottonischer Zeit (Stuttgart, 2006), 82. 
in 500, with Constans II in 662 and with Charlemagne in 774, to mention just a few of the most prominent visitors of Rome. ${ }^{15}$ For the Carolingians in general, Saint Peter's was an important point of reference: in 781 Carloman, the son of Charlemagne, was baptised and anointed king by Pope Hadrian in Saint Peter's and not in the old episcopal baptistery at the Lateran, and Saint Peter's basilica also represented a very effective backdrop for the imperial coronation of Charlemagne on Christmas day in 800. ${ }^{16}$ Moreover, from about 760 the Carolingians used the old imperial mausoleum, now under the patronage of Saint Petronilla, as their private oratory. ${ }^{17}$ That they also owned a palace near Saint Peter's and published important political announcements on the church's façade (or rather on its atrium) might round off the picture. ${ }^{18}$

What about the pope? He was always an active protagonist in these performances of political alliances and was very aware of the high symbolic value that Saint Peter's had on these occasions. Sible de Blaauw has rightly called Saint Peter's the 'centro simbolico dal quale il vescovo di Roma esercita la propria autorità. ${ }^{19}$ The fact that the popes claimed Saint Peter's as their own burial site as early as the second half of the fifth century (and therefore just after the last members of the dynasty of the western

15 M. Humphries, 'From emperor to Pope? Ceremonial, space, and authority at Rome from Constantine to Gregory the Great', in K. Cooper and J. Hillner (eds.), Religion, Dynasty, and Patronage in Early Christian Rome, 300-900 (Cambridge, 2007), 21-58, at p. 47 (Honorius and Valentinian III), 48 (Theoderic), 56 (Constans II); P. Liverani, 'Saint Peter's and the city of Rome between Late Antiquity and the early Middle Ages', in McKitterick et al. (eds.), Old Saint Peter's, Rome, 21-34, at pp. 30-3; R. McKitterick, 'The representation of Old Saint Peter's basilica in the Liber Pontificalis', in McKitterick et al. (eds.), Old Saint Peter's, Rome, 95-118, esp. pp. 100-1. For Theoderic, see Anon. Vales. c. 65-7, in I. König, Aus der Zeit Theoderichs des Großen: Einleitung, Text, Übersetzung und Kommentar einer anonymen Quelle (Darmstadt, 1997), 82-5; M. Vitiello, 'Teodorico a Roma: Politica, amministrazione e propaganda nell'adventus dell'anno 500 (considerazioni sull'Anonimo Valesiano II)', Historia 53 (2004), 73-120. On the adventus of Constans II, see LP I, Life 78, 343 (c. 2); on the adventus of Charlemagne in the year 774, see LP I, Life 97, 497 (c. 37-8); Scholz, Politik - Selbstverständnis Selbstdarstellung, 81-2.

16 Scholz, Politik - Selbstverständnis - Selbstdarstellung, 64 and 89; for the coronation of Charlemagne, see 126-35, esp. 132. See also F. A. Bauer, Das Bild der Stadt Rom im Frühmittelalter: Papststiftungen im Spiegel des Liber Pontificalis von Gregor dem Dritten bis zu Leo dem Dritten (Wiesbaden, 2004), 91-120; J. Story, 'The Carolingians and the oratory of Saint Peter the Shepherd', in McKitterick et al. (eds.), Old Saint Peter's, Rome, 257-73.

17 On Saint Petronilla, see M. Borgolte, Petrusnachfolge und Kaiserimitation: Die Grablege der Päpste, ihre Genese und Traditionsbildung (Göttingen, 1989), 110; Scholz, PolitikSelbstverständnis - Selbstdarstellung, 67; McKitterick et al., 'Introduction', 5.

18 C. R. Brühl, 'Die Kaiserpfalz bei St. Peter und die Pfalz Ottos III. auf dem Palatin', Quellen und Forschungen aus römischen Archiven und Bibliotheken 34 (1935), 1-30; Bauer, Das Bild der Stadt Rom im Frühmittelalter, 177; Humphries, 'From emperor to Pope?' 48.

19 Blaauw, CD II, 515. 
Roman Empire had been buried there) shows that they weren't willing to leave the memorial church above the tomb of their saintly predecessor to the worldly rulers. ${ }^{20}$ Their donation policy gives the impression that the popes were keen to keep up with the donations of worldly sovereigns to Saint Peter's in order not to lose control over this highly symbolic place and to be 'present' there in a visible way. ${ }^{21}$

Besides that, the above-mentioned baptistery at Saint Peter's demonstrated papal presence at the Vatican as well. It had probably been founded by Pope Damasus, but it had surely existed since the fifth century and was converted into a replica of the Lateran baptistery by Pope Symmachus in the first years of the sixth century. ${ }^{22}$ Thus Saint Peter's was presented as a branch of the Lateran, or rather as a fully adequate replacement for the cathedral. Symmachus, by erecting three oratories annexed to the baptistery in Saint Peter's, reinstalled there exactly the same chapel programme that Pope Hilarus (461-8) had set up at the Lateran baptistery only a few years before. ${ }^{23}$ In both Saint Peter's and the Lateran two of the three chapels were dedicated to the two Saint Johns - the Evangelist and the Baptist - whereas the third was dedicated to the Holy Cross and received a corresponding relic. ${ }^{24}$ Unfortunately,

20 Borgolte, Petrusnachfolge und Kaiserimitation, esp. 49-93; McKitterick, 'The representation of Old Saint Peter's basilica', 105-17.

21 For the donations of worldly sovereigns to Saint Peter's, see F. A. Bauer, 'Herrschergeschenke an Sankt Peter', Mitteilungen zur Spätantiken Archäologie und Byzantinischen Kunstgeschichte 4 (2005), 65-99. On papal donations to Saint Peter's, see Blaauw, CD II, 482-5; J. Alchermes, 'Petrine Politics: Pope Symmachus and the Rotunda of St. Andrew at Old St. Peter's', Catholic Historical Review 81 (1995), 1-40, at pp. 10-1; Bauer, Das Bild der Stadt Rom im Frühmittelalter, passim.

22 LP I, Life 53, 261-2 (c. 7). For the building initiatives of Pope Symmachus in Saint Peter's, especially the oratoria of the baptistery, see J. H. Emminghaus, 'Die Taufanlage ad sellam Petri confessionis', Römische Quartalschrift 57 (1962), 78-103, esp. 78-82 and 93-5; Blaauw, CD II, 485-6; Alchermes, 'Petrine Politics', 15-17; Brandenburg, 'Das Baptisterium und der Brunnen', 67-70; A. Guiglia, 'Il VI secolo: da Simmaco (498-514) a Gregorio Magno (590-604)', in M. D’Onofrio (ed.), La committenza artistica dei papi a Roma nel Medioevo (Rome, 2016), 109-43, at p. 111.

23 For the chapels annexed by Hilarus to the Lateran baptistery, see LP I, Life 48, 242-3 (c. 2-5); Blaauw, CD I, 135-40; M. J. Johnson, 'The fifth-century oratory of the Holy Cross at the Lateran in Rome', Architectura. Zeitschrift für die Geschichte der Baukunst 25, 2 (1995), 128-55; G. Mackie, 'The Sancta Croce drawings: A re-examination', Revue d'art Canadienne/Canadian Art Review 24, 1 (1997), 1-14; O. Brandt, 'L'oratorio della Santa Croce', in P. Liverani (ed.), Giornata di studio tematica dedicata al Patriarcato Lateranense: Atti della giornata tematica dei Seminari di Archeologia Cristiana (École française de Rome, 10 maggio 2001) (MEFRA 116, 1) (special issue) (Rome, 2004), 79-93; O. Brandt, Battisteri oltre la pianta: Gli alzati di nove battisteri paleocristiani in Italia (Vatican City, 2012), 33-85; M. Gianandrea, 'Il V secolo: Da Innocenzo I (401-417) ad Anastasio II (496-498)', in D’Onofrio (ed.), La committenza artistica dei papi, 73-108, at pp. 93-6. See also Brandt, Chapter 11 in this volume.

24 See previous two notes. For both constructions see also S. de Blaauw, 'Jerusalem in Rome and the cult of the Cross', in R. Colella and R. Krautheimer (eds.), Pratum Romanum: Richard Krautheimer zum 100. Geburtstag (Wiesbaden, 1997), 55-73, esp. 68-9. 
how this triad of chapels at the Vatican presented itself is in doubt, and even the position and shape of the baptistery are still disputed. ${ }^{25}$ On the late sixteenth-century ground plan designed by Tiberio Alfarano (Fig. 15.2), the piscina and the three altars belonging to the three chapels are situated in the north transept, but it is not clear if this situation goes back to the early Middle Ages, or even to the fourth century. Most recently, Olof Brandt assumed that the early Christian baptistery of Saint Peter's was attached to the north transept as a free-standing central-plan building with the annexed chapels. Only when Pope Hadrian IV (1154-9) raised the transept would the baptistery and the annexed chapels have been pulled down and transferred into the transept as shown on Alfarano's plan. ${ }^{26}$ Emminghaus and others have argued for locating the baptistery of Saint Peter's in the north transept from the beginning; the fons would then initially have been situated in a small apse, and only with Leo III (795-816) would it have been moved to the centre of the transept and remodelled as a free-standing piscina, as in the Lateran baptistery. ${ }^{27}$ Unfortunately this cannot be finally determined, either through archaeological evidence or through pictures or written sources, as these are contradictory in many respects. For my purpose, however, this does not matter. In the context of my interests it is primarily important that it seems to have been essential to Symmachus - regardless of the final architectural implementation - to have a liturgical disposition at the Vatican that allowed him to celebrate baptisms according to the same rite as in the episcopal baptistery at the Lateran. Probably this project of a functional - if not formal - replica fell into the period 501-6, when Symmachus had no access to the cathedral and its baptistery in the

25 Schumacher, 'Das Baptisterium von Alt-St. Peter' (with localisation of the Damasian baptistery in the Western Rotunda on the south side of the transept of Saint Peter's and its relocation in the northern wing of the transept in the time of Leo III); Blaauw, CD II, 485-91 (with localisation of the early Christian baptistery in the northern wing of the transept); Brandenburg, 'Das Baptisterium und der Brunnen' (like de Blaauw). See also n. 22 and 23.

26 Brandt, 'The early Christian baptistery', 91-4; see Mackie, 'The Sancta Croce drawings', 5-11. From Peter Mallius and other sources of the twelfth century we learn that at this time at the latest the arrangement was the one documented by Alfarano in the sixteenth century: R. Valentini and G. Zucchetti, Codice topografico della città di Roma, 4 vols. (Fonti per la Storia d'Italia 90) (Rome, 1940-53), III, 422-3; Schumacher, 'Das Baptisterium von Alt-St. Peter', 231-2. See also the description written in 1452 by Nikolaus Muffel, who verifies the arrangement documented by Alfarano posthumously on the basis of proper inspection; interestingly enough, the disposition in Saint Peter's with the six columns around the piscina reminded Muffel of 'Sant Johanns latron': N. Muffel, Descrizione della città di Roma nel 1452: Delle indulgenze e dei luoghi sacri di Roma (Der ablas und die heiligen stet zu Rom), ed. and trans. D. G. Wiedmann (Bologna, 1999), 54-5.

27 Emminghaus, 'Die Taufanlage'; Blaauw, CD II, 491. See also L. Duchesne, in LP I, 266, nn. 20-2. 


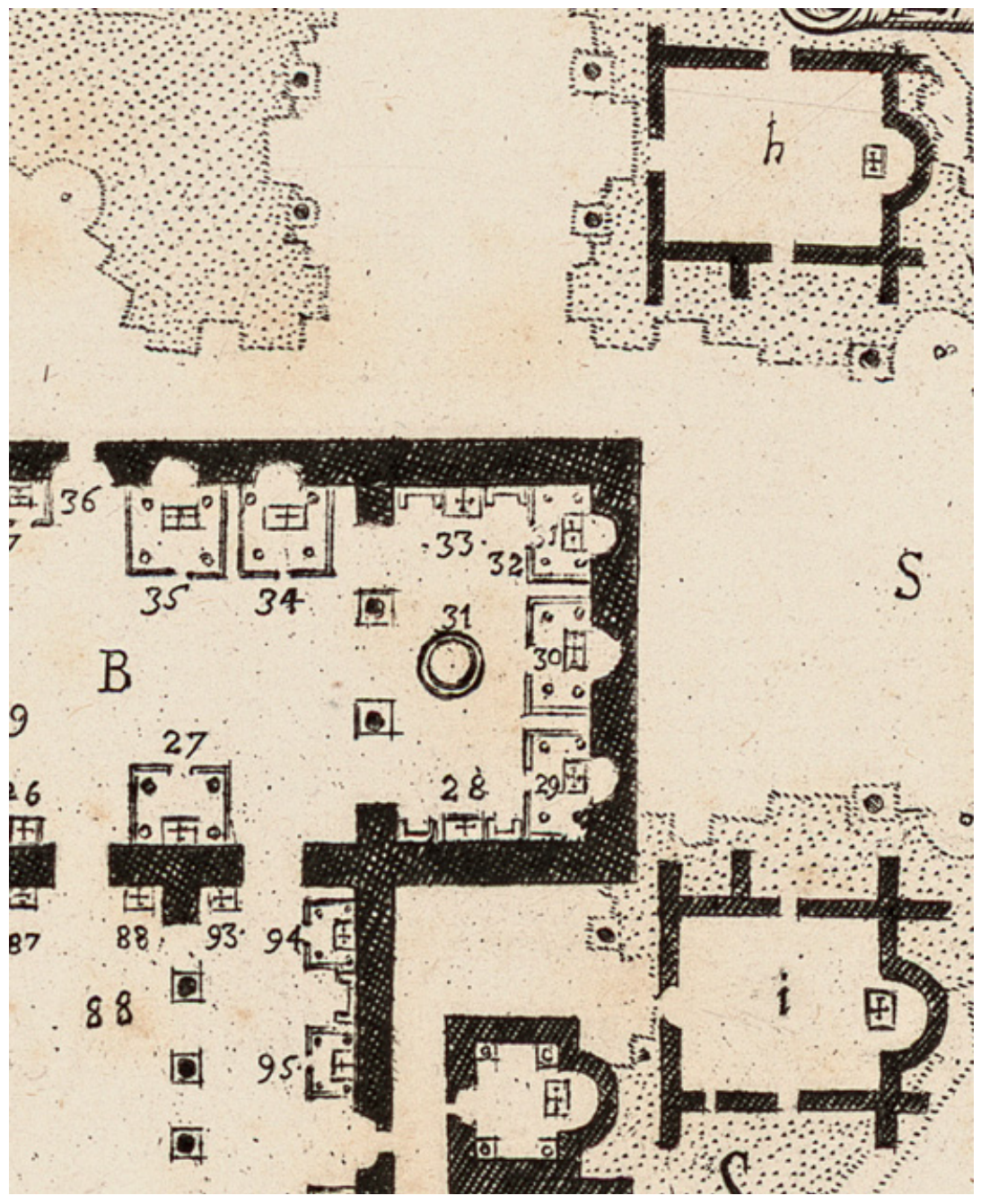

Fig. 15.2 T. Alfarano: Plan of Saint Peter's (detail of the northern part of the transept with the piscina of the baptistery and the chapels of Saint John the Evangelist (no. 32), Saint John the Baptist (no. 30) and the Holy Cross (no. 35) (Bibliotheca Hertziana Max Planck-Institut für Kunstgeschichte, Rome).

aftermath of the conflicts with Laurentius, who was elected pope on the same day as Symmachus himself had been elected, and who occupied the Lateran claiming to be the legitimate pope. ${ }^{28}$ It fits with the scenario

28 J. Richards, The Popes and the Papacy in the Early Middle Ages 476-752 (London, 1979), 80-91; E. Wirbelauer, Zwei Päpste in Rom: Der Konflikt zwischen Laurentius und Symmachus (498-514): Studien und Texte (Quellen und Forschungen zur antiken Welt 16) (Munich, 1993), esp. 34-7; C. Laudage, Kampf um den Stuhl Petri: Die Geschichte der Gegenpäpste (Freiburg, 2012), 42-6; Thacker, 'Popes, emperors and clergy', 151-3. At the same period, around 500, the 
that Symmachus not only structurally optimised the accessibility of Saint Peter's but also built episcopia next to the atrium. ${ }^{29}$ With these apparently residential and administrative buildings, he actually laid the foundation for today's layout.

Compared with this, the Lateran basilica got remarkably less attention in the first centuries of its existence. ${ }^{30}$ The cathedral of Rome did not possess a saint at whose grave people could pray for healing or who could act as an intercessor. Still, we can observe a process of enhancement concerning the Lateran during the early Middle Ages, focused less on the basilica and its liturgical furnishings than on the nearby papal palace. ${ }^{31}$ From the sixth century onwards, and especially in the decades after the establishment of the Patrimonium Petri by Pippin in 756, the papal palace at the Lateran was modelled after the Byzantine imperial palace of Constantinople, and thus turned into one of the most important residences in Europe. ${ }^{32}$ Together with the piazza in front of it, the palace served as the backdrop of the increasingly imperialistic self-representation of the pope. Another part of this enhanced appreciation was the accumulation of sacred assets in the palace in the form of highly potent relics of Christ. Through these relics the papal chapel became styled as the Sancta Sanctorum, the Lateran as a new

Gesta Liberii were written, which claimed that Pope Liberius, expelled by Constantine from Rome, was prompted by his deacon, Damasus, to install a baptistery at Saint Peter's because he feared not being able to celebrate Pentecost at the Lateran: Schumacher, 'Das Baptisterium von Alt-St. Peter', 225; Blaauw, CD II, 489.

${ }^{29}$ LP I, Life 53, 262 (c. 7) and 267, n. 25. Pope Leo III extended the Vatican residence: LP II, Life 98, 1 (c. 3). A discussion on the position of the Symmachian episcopia and the Leonine residence at the Vatican can be found in K. Steinke, Die mittelalterlichen Vatikanpaläste und ihre Kapellen: Baugeschichtliche Untersuchungen anhand der schriftlichen Quellen (Vatican City, 1984), 11-32; A. Monciatti, Il Palazzo Vaticano nel Medioevo (Florence, 2005), 93-5. See also Bauer, Das Bild der Stadt Rom im Frühmittelalter, 174-6.

${ }^{30}$ See Liverani, 'Saint Peter's and the city of Rome', 30-4.

31 On the early medieval building activities in the Lateran, see CBCR V, 11; Claussen, 'S. Giovanni in Laterano', 29-30; Blaauw, CD I, 163-9. For the papal residence at the Lateran, its constructive evolution and its political dimensions, see next note.

${ }^{32}$ M. Luchterhandt, 'Vom Haus des Bischofs zum Locus Sanctus: Der Lateranspalast im kulturellen Gedächtnis des römischen Mittelalters', in M. Featherstone, J.-M. Spieser, G. Tanman and U. WulfRheidt (eds.), The Emperor's House: Palaces from Augustus to the Age of Absolutism (Berlin, 2015), 73-92; X. Barral i Altet, 'L'VIII secolo: Da Giovanni VI (701-705) ad Adriano I (772-795)', in D’Onofrio (ed.), La committenza artistica dei papi, 181-212, at pp. 202-4. See also I. Herklotz, 'Der Campus Lateranense im Mittelalter', Römisches Jahrbuch für Kunstgeschichte 22 (1985), 1-43, esp. 36-7 and 41; Bauer, Das Bild der Stadt Rom im Frühmittelalter, 61-75; Liverani (ed.), Giornata di studio, esp. the chapter by U. Real, at pp. 95-108); Monciatti, Il Palazzo Vaticano nel Medioevo, $1-29$. For the references to the imperial palace in Constantinople - also in view of the possession of relics and their political instrumentalisation - see H. A. Klein, 'Sacred relics and imperial ceremonies at the great palace of Constantinople', in F. A. Bauer (ed.), Visualisierungen von Herrschaft: Frühmittelalterliche Residenzen - Gestalt und Zeremoniell (Istanbul, 2006), 79-99. 
Jerusalem, and its guardian, the pope, as the high priest of the Holy of Holies. ${ }^{33}$ It was surely not by accident that the arca commissioned in the years around 800 by Leo III (795-816) for the papal relic treasure was made of wood (Fig. 15.3) - like the Ark of the Covenant. ${ }^{34}$ Compared with the 'super relic' of Saint Peter's, the tomb of Saint Peter, the relics that were kept in the papal chapel had the advantage of being mobile, so they could be carried around in processions. Their holiness was therefore not limited to the Lateran only, but on certain occasions also reached out to the city. ${ }^{35}$

For a long time the Lateran seems to have been mainly the site of encounters between the pope and the Romans. ${ }^{36}$ Thus, until the end of Byzantine rule in Italy it was here, in the patriarchium, that the Romans acclaimed the new emperor after his election in the form of his effigies that had been sent to Rome. ${ }^{37}$ But visits by actual rulers to the Lateran are scarcely documented, either in the palace or in the basilica. ${ }^{38}$ Interestingly

33 The name 'Sancta Sanctorum' for the papal chapel in the Lateran palace is not attested earlier than the eleventh century: H. Grisar, Die römische Kapelle Sancta Sanctorum und ihr Schatz: Meine Entdeckungen und Studien in der Palastkapelle der mittelalterlichen Päpste (Freiburg 1908), 16 and 57; O. Nussbaum, 'Sancta Sanctorum', Römische Quartalschrift 54 (1959), 234-46, at pp. 242-4; S. de Blaauw, 'Il Patriarchio, la Basilica Lateranense e la liturgia', in Liverani (ed.), Giornata di studio, 161-71, at p. 171. Some scholars suggest that the papal relic treasure was called 'Santa Sanctorum' as early as the ninth century: Nussbaum, 'Sancta Sanctorum', 243; E. Thunø, Image and Relic: Mediating the Sacred in Early Medieval Rome (Analecta Romana Instituti Danici, Supplementum 32) (Rome, 2002), 161 and n. 438. See also G. Cornini, "Non est in toto sanctior orbe locus": Collecting relics in early medieval Rome', in M. Bagnoli, H. A. Klein, C. Griffith Mann and J. Robinson (eds.), Treasures of Heaven: Saints, Relics, and Devotion in Medieval Europe (Baltimore, 2010), 69-78, esp. p. 71. For the chapel and its relics, see also R. Colella, 'Hagiographie und Kirchenpolitik: Stephanus und Laurentius in Rom', in Colella and Krautheimer (eds.), Pratum Romanum, 75-96, esp. pp. 87-8; M. Cempanari, Sancta Santorum Lateranense: Il Santuario della Scala Santa dalle origini ai nostri giorni, 2 vols. (Rome, 2003); Bauer, Das Bild der Stadt Rom im Frühmittelalter, 75-80.

34 Grisar, Die römische Kapelle, 56 f.; Thunø, Image and Relic, 160-6 and 168-9; Bauer, Das Bild der Stadt Rom im Frühmittelalter, 75 and figs. 26-8 at pp. 72-4; Cornini, "Non est in toto sanctior orbe locus"', 70-1.

35 Blaauw, CD I, 195-8 and 313-6. This is especially true for the most venerated icon of the Saviour, sixth-seventh century: Grisar, Die römische Kapelle, 39-54 and 58-137; G. Wolf, Salus Populi Romani: Die Geschichte römischer Kultbilder im Mittelalter (Weinheim, 1990), 29-78; E. Parlato, 'Le icone in processione', in M. Andaloro and S. Romano (eds.), Arte e iconografia a Roma dal Tardoantico alla fine del Medioevo (Milan, 2002), 64-8; S. Romano, 'L'icône acheiropoiete du Latran: Fonction d'une image absente', in Bock et al. (eds.), Art, cérémonial et liturgie, 301-19; Thunø, Image and Relic, 15-17; Cornini, “Non est in toto sanctior orbe locus"', 72-4; A. van Dijk, 'The Veronica, the Vultus Christi and the veneration of icons in medieval Rome', in McKitterick et al. (eds.), Old Saint Peter's, Rome, 229-56, at pp. 233 and 237; Luchterhandt, 'Vom Haus des Bischofs', 82-6.

36 Herklotz, 'Der Campus Lateranense', 8.

37 Herklotz, 'Der Campus Lateranense', 39; Humphries, 'From emperor to Pope?' 21 and 56.

38 One exception seems to have been the visit of Emperor Constans II in 662; like other sovereigns visiting Rome, Constans resided during his stay in the old imperial palace on the Palatine and 


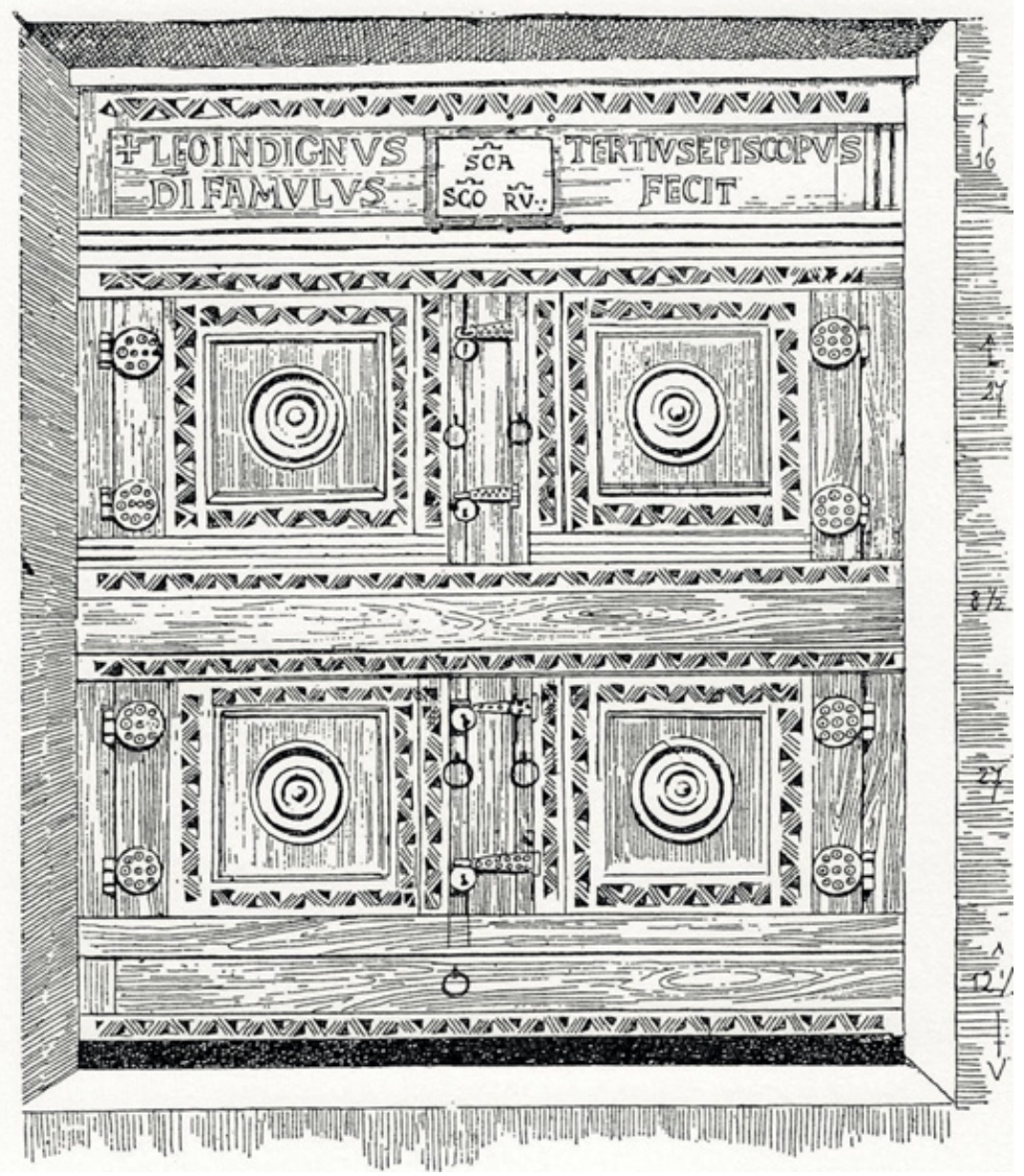

Fig. 15.3 Drawing of the wooden arca commissioned by Pope Leo III (795-816) (from Grisar, Die römische Kapelle).

enough, the basilica played no role at all in the presentation of the relics in the early Middle Ages - this changed only in the high Middle Ages. ${ }^{39}$ In the early Middle Ages the holiness of the Lateran relics was totally focused on

set a high value on his visit to Saint Peter's at the Vatican, but he also was received by Pope Vitalian in the papal palace at the Lateran: LP I, Life 78, 343 (c. 3). Even Charlemagne, after having prayed at the tomb of Saint Peter during the Easter festivities in 774, was invited by the pope to join baptismal mass in the Lateran basilica and to dine with him in the Lateran palace: LP I, Life 97, 497 (c. 39). See Scholz, Politik - Selbstverständnis - Selbstdarstellung, 82.

39 Herklotz, 'Der mittelalterliche Fassadenportikus', 85; Blaauw, CD I, 318-19; L. Burkart, 'Die Aufhebung der Sichtbarkeit: Der Schatz der Sancta Sanctorum und die Modi seiner visuellen Inszenierung', in A. Rathmann-Lutz (ed.), Visibilität des Unsichtbaren: Sehen und Verstehen in Mittelalter und früher Neuzeit (Zurich, 2011), 69-82, at p. 73; D. Mondini, 'Reliquie incarnate: 
the patriarchium, and especially on the papal chapel that was dedicated to Saint Lawrence. ${ }^{40}$ On the other hand, the Liber Pontificalis documents that Pope Sergius II (844-7) had a confessio set up shortly before the middle of the ninth century. ${ }^{41} \mathrm{He}$ thus established a liturgical disposition in the cathedral that since the time of Gregory the Great had become customary for Roman churches with a saint's tomb or other high-grade body relics. Even though the nature of the relics in the Lateran basilica is unknown, the new confessio is evidence of an attempt to rectify the lack of precious relics, which was obviously considered a deficit. ${ }^{42}$ However, in view of the claim that the Lateran basilica was the 'head and summit of all churches on earth' (caput et vertex omnium ecclesiarum in universo orbe terrarum) - as it was formulated for the first time in the Constitutum Constantini around the middle of the eighth century - this attempt appears quite desperate. ${ }^{43}$

\section{The Situation in the High and Late Middle Ages}

In the aftermath of the Investiture Controversy, the Lateran's claim to be the first of all churches grew increasingly explicit. ${ }^{44}$ Ingo Herklotz and others have shown in various publications how papacy and Lateran formed an 'inseparable unit' in the high Middle Ages and how the Lateran basilica became the 'material symbol of the Roman church' par excellence; the famous dream vision of Innocent III who saw Saint Francis rescuing the

Le "sacre teste" di Pietro e Paolo a San Giovanni in Laterano a Roma', in D. Scotto (ed.), Del visibile credere: Pellegrinaggi, santuari, miracoli, reliquie (Florence, 2011), 265-96, at p. 274.

40 De Blaauw, 'Il Patriarchio', 164-5. ${ }^{41}$ LP II, Life 104, 91 (c. 19).

42 Blaauw, CD I, 174-6; Claussen, 'S. Giovanni in Laterano', 186.

43 Constitutum Constantini, c. 13: H. Fuhrmann (ed.), Das Constitutum Constantini (Konstantinische Schenkung), Text (MGH Fontes Iuris Germanici Antiqui in usum scholarium ex Monumentis Germaniae Historicis separatim editi 10) (Hanover, 1968), 84-5: 'Interea nosse volumus omnem populum universarum gentium ac nationum per totum orbem terrarum, construxisse nos intro palatium nostrum Lateranense eidem salvatori nostro domino Iesu Christo ecclesiam a fundamentis cum baptisterio ... ; quam sacrosanctam ecclesiam caput et verticem omnium ecclesiarum in universo orbe terrarum dici, coli, venerari ac praedicari sancimus, sicut per alia nostra imperialia decreta statuimus'. See Herklotz, 'Der Campus Lateranense', 38; Blaauw, CD I, 164-5.

44 One of the medieval authors quoting the honorary title given to the Lateran basilica in the Constitutum Constantini was Pier Damiani († 1072), Epist. II 1, 255 (see Blaauw, CD I, 204). In official documents of this time (for instance in the bull that Pope Anastasius IV issued in December 1153), the Lateran basilica is mentioned as 'basilica Salvatoris domini, que Constantiniana vocatur, pariterque beati Iohannis baptiste et Iohannis evangeliste': J. von PflugkHarttung, Acta pontificum romanorum inedita, vol. III: Urkunden der Päpste 590-1197 (Graz, 1958), 133. 


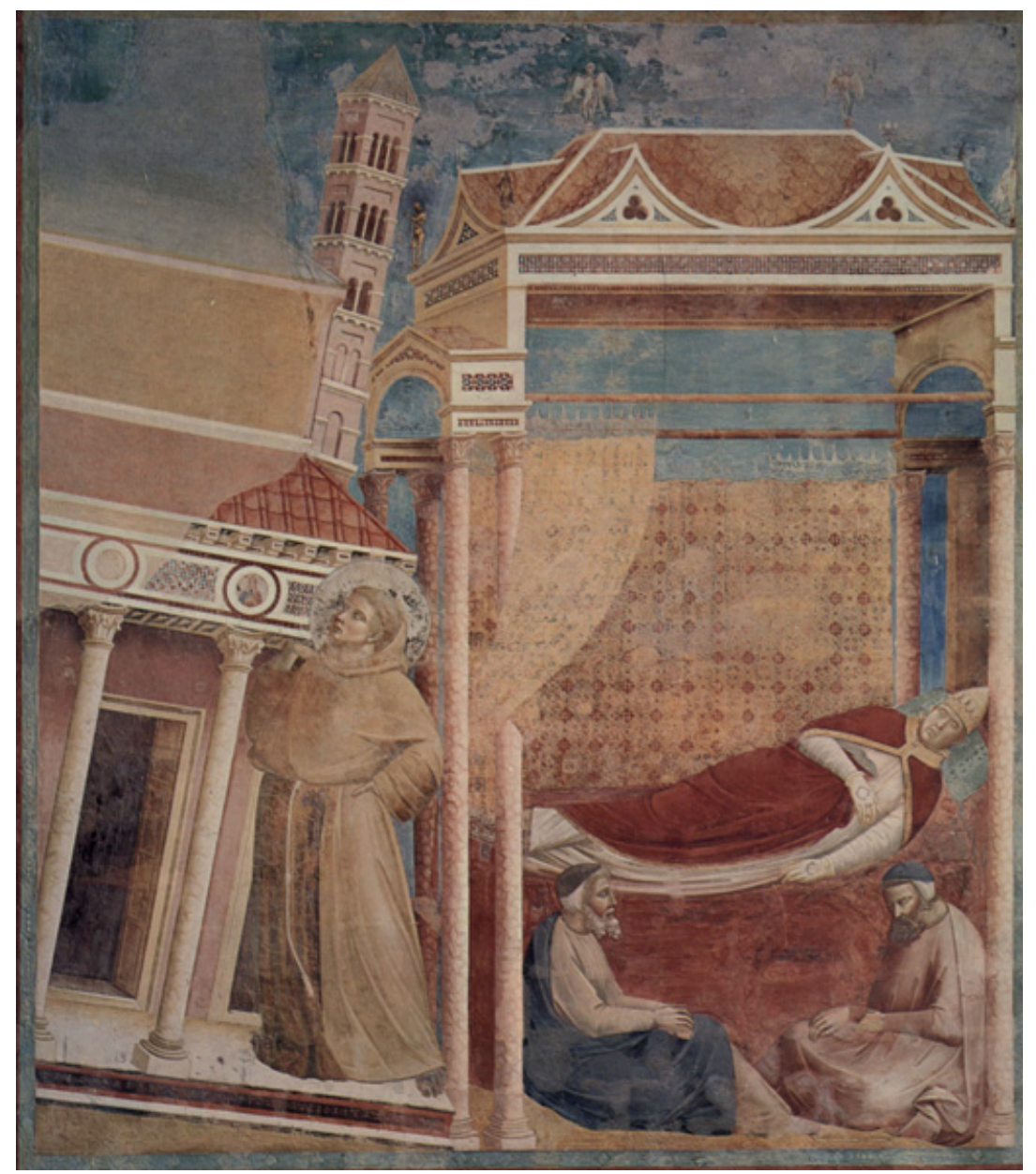

Fig. 15.4 Giotto: Fresco in Saint Francis, Assisi, showing Saint Francis acting as support for the collapsing Lateran basilica (= Roman Church) (commons.wikimedia.org/wiki/ File:Giotto_di_Bondone_(und_Werkstatt)_001.jpg).

Church by underpinning the collapsing Lateran basilica (Fig. 15.4) might be the most obvious proof of this. ${ }^{45}$

The new understanding of the old Constantinian cathedral manifested itself in different media. This is particularly the case with the mosaic images and the inscription on the portico that was built in front of the eastern façade in the late twelfth century, but also, and most of all, with the papal tombs. ${ }^{46}$

45 Herklotz, 'Der mittelalterliche Fassadenportikus', 71.

46 See below. Another interesting element in this context are the murals of the twelfth century in the patriarchium with their highly political iconography: C. Walter, 'Papal political imagery in the Medieval Lateran Palace', Cahiers Archéologiques 20 (1970), 155-76 (part 1) and Cahiers 
By the tenth century some popes had chosen the Lateran basilica as their burial place. ${ }^{47}$ By doing so, they had broken with the old tradition of papal burials in Saint Peter's, instituted by Leo the Great in the middle of the fifth century. ${ }^{48}$ The ban on burying the dead inside the city walls had been flaunted with increasing frequency from around the end of Late Antiquity, and since Carolingian times this practice had been sanctioned by corresponding legislation. ${ }^{49}$ In addition, Saint Peter's had lost its extra-muros position after 846 when Leo IV included its borgo in the fortified area of the city. ${ }^{50}$ But all this does not sufficiently explain why John $\mathrm{X}$ in 928 and perhaps already Leo $\mathrm{V}(† 903)$ preferred to be buried in the cathedral instead of the old papal burial place near the tomb of Saint Peter in the Vatican. ${ }^{51}$ Was it because in those years, under Pope Sergius III (904-11), the cathedral regained its old splendour after an earthquake had seriously damaged it in $896 ?^{52}$ Or was it because already then, by the early tenth century, the Lateran

Archéologiques 21 (1971), 109-36 (part 2); Borgolte, Petrusnachfolge und Kaiserimitation, 152-7;

I. Herklotz, 'Die Beratungsräume Calixtus' II. im Lateranspalast und ihre Fresken: Kunst und Propaganda am Ende des Investiturstreits', Zeitschrift für Kunstgeschichte 52 (1989), 145-214; J. Johrendt, 'Das Innozenzische Schisma aus kurialer Perspektive', in H. Müller and B. Hotz (eds.), Gegenpäpste: Ein unerwünschtes mittelalterliches Phänomen (Vienna, 2012), 127-63, at pp. 136-42; D. Kinney, 'Patronage of art and architecture', in J. Doran and D. J. Smith (eds.), Pope Innocent II (1130-1143): The World vs. the City (Abingdon, 2016), 352-87, at pp. 381-4.

47 Borgolte, Petrusnachfolge und Kaiserimitation, 127-32 (for the papal tombs of the eleventh and twelfth centuries in the Lateran, see pp. 129-30, 135-6, 152-78); A. Paravicini Bagliani, Il corpo del Papa (Turin, 1994), 20-1 and 61-2, n. 57; I. Herklotz, 'Sepulcra' et 'Monumenta' del Medioevo: Studi sull'arte sepolcrale in Italia (Naples, 2001), 136-7.

${ }^{48}$ See above, n. 20.

49 R. Meneghini and R. Santangeli Valenzani, 'Sepolture intramuranee e paesaggio urbano a Roma tra V e VII secolo', in L. Paroli and P. Delogu (eds.), La storia economica di Roma nell'alto medioevo alla luce dei recenti scavi archeologici (Florence, 1993), 89-111; R. Meneghini and R. Santangeli Valenzani, 'Sepolture intramuranee e paesaggio urbano a Roma tra V e VII secolo d.C.: Aggiornamenti e considerazioni', Archeologia Medievale 22 (1995), 283-90;

M. Costambeys, 'Burial topography and the power of the Church in fifth- and sixth-century Rome', PBSR 69 (2001), 169-89. See also G. Cantino Wataghin, 'The ideology of urban burials', in G. P. Brogiolo and B. Ward Perkins (eds.), The Idea and Ideal of the Town between Late Antiquity and the Early Middle Ages (Leiden, 1999), 147-80.

50 For the civitas Leonina, see LP II, Life 105, 123; Bauer, Das Bild der Stadt Rom im Frühmittelalter, 177-8; Scholz, Politik - Selbstverständnis - Selbstdarstellung, 175-6; McKitterick et al., 'Introduction', 6.

51 Blaauw, CD I, 258-9; Herklotz, 'Sepulcra' et 'Monumenta', 137; Claussen, 'S. Giovanni in Laterano', 216.

52 CBCR V, 11-12; Claussen, 'S. Giovanni in Laterano', 29-31; G. De Spirito, 'La Basilica Lateranense nel quadro delle vicende del Patriarcato del secolo X', in Liverani (ed.), Giornata di studio, 117-39; G. Pollio, 'Il X secolo: Da Benedetto IV (900-903) a Gregorio V (996-999)', in D'Onofrio (ed.), La committenza artistica dei papi, 239-54. As the earthquake of 896 is not verified by other sources it does not figure in the list of historically proven earthquakes: R. Budriesi, 'I terremoti e l'edilizia religiosa a Roma e a Ravenna tra VII/X secolo', in 
was linked to Mount Sinai as a place of divine legislation? ${ }^{53}$ Or because the popes wanted to state their presence at the place of their ministry, 'in sede propria', as we can read in the Liber Pontificalis concerning the tomb of Paschal II? ${ }^{54}$ Whatever the reason, from this time on many popes chose the Lateran basilica as their final resting place. ${ }^{55}$ But as the papal tombs of the tenth and the first half of the eleventh centuries at the Lateran had been placed in the floor near the façade, either in the portico or within the church near the entrances, from the Investiture Controversy onwards the tombs arose self-confidently in the western part of the nave and in the south transept - that is, in the centre of the liturgical activity and in the area of passage towards the chapter's cloister. ${ }^{56}$ Antique sarcophagi were reused for many of these papal burials - in the case of Innocent II ( $\dagger 1143)$ and Anastasius IV ( $† 1154)$, even imperial sarcophagi from the mausoleums of Hadrian and the empress Helena (Fig. 15.5). ${ }^{57}$ Yet by their mere material, the red porphyry with its explicitly imperial connotations, these sarcophagi revealed with whom the popes of that time competed.

The above-mentioned portico of the late twelfth century, however, with its admittedly not very large-format mosaic images on its frieze (Figs 15.6 and 15.7), unequivocally presented subjects that showed quite plainly the papal claim to power. ${ }^{58}$ In most of the images this claim was linked to the concrete site, the Lateran, whether by the image of the baptism of Constantine or the Donatio Constantini, by the depiction of the heads of the two apostles which the Lateran claimed to have possessed since the second half of the eleventh century, or by the scene with the conquest

E. Guidoboni (ed.), I terremoti prima del Mille in Italia e nell'area mediterranea: Storia archeologia sismologia (Bologna, 1989), 364-87.

53 De Spirito, 'La Basilica Lateranense', 120. See also n. 33 above.

54 LP II, Life 161, 305; Herklotz, 'Sepulcra' et 'Monumenta', 146-7. See also Paravicini Bagliani, Il corpo del Papa, 20 and 62 n. 58.

55 Blaauw, CD I, 204-5.

${ }^{56}$ For the position of the tombs, see Blaauw, CD II, 258-61 and fig. 8; Claussen, 'S. Giovanni in Laterano', 69 and 218-19.

57 Herklotz, 'Der Campus Lateranense', 3, 11 and 42; Borgolte, Petrusnachfolge und Kaiserimitation, 163-5 and 169-71; S. de Blaauw, 'Papst und Purpur. Porphyr in frühen Kirchenausstattungen in Rom', in E. Dassmann and K. Thraede (eds.), Tesserae. Festschrift für Josef Engemann (Jahrbuch für Antike und Christentum, Ergänzungsband 18) (Münster, 1991), 36-50, esp. 47; Blaauw, CD I, 261-2; Paravicini Bagliani, Il corpo del Papa, 21; Herklotz, 'Sepulcra' et 'Monumenta', 147-54, 173-6 and 195-203; Claussen, 'S. Giovanni in Laterano', 217-19; most recently, see Kinney, 'Patronage of art and architecture', 384-7.

58 Nine of the originally more than twenty scenes are known from drawings by Ciampini and others: Herklotz, 'Der mittelalterliche Fassadenportikus', 48-53; Claussen, 'S. Giovanni in Laterano', 78-84. For the construction history of the portico and its dating, see Herklotz, 'Der mittelalterliche Fassadenportikus'; Claussen, 'S. Giovanni in Laterano', 31-2 and 63-77. See also F. Pomarci, 'Medioevo: Architettura', in Pietrangeli (ed.), San Giovanni in Laterano, 63-6. 


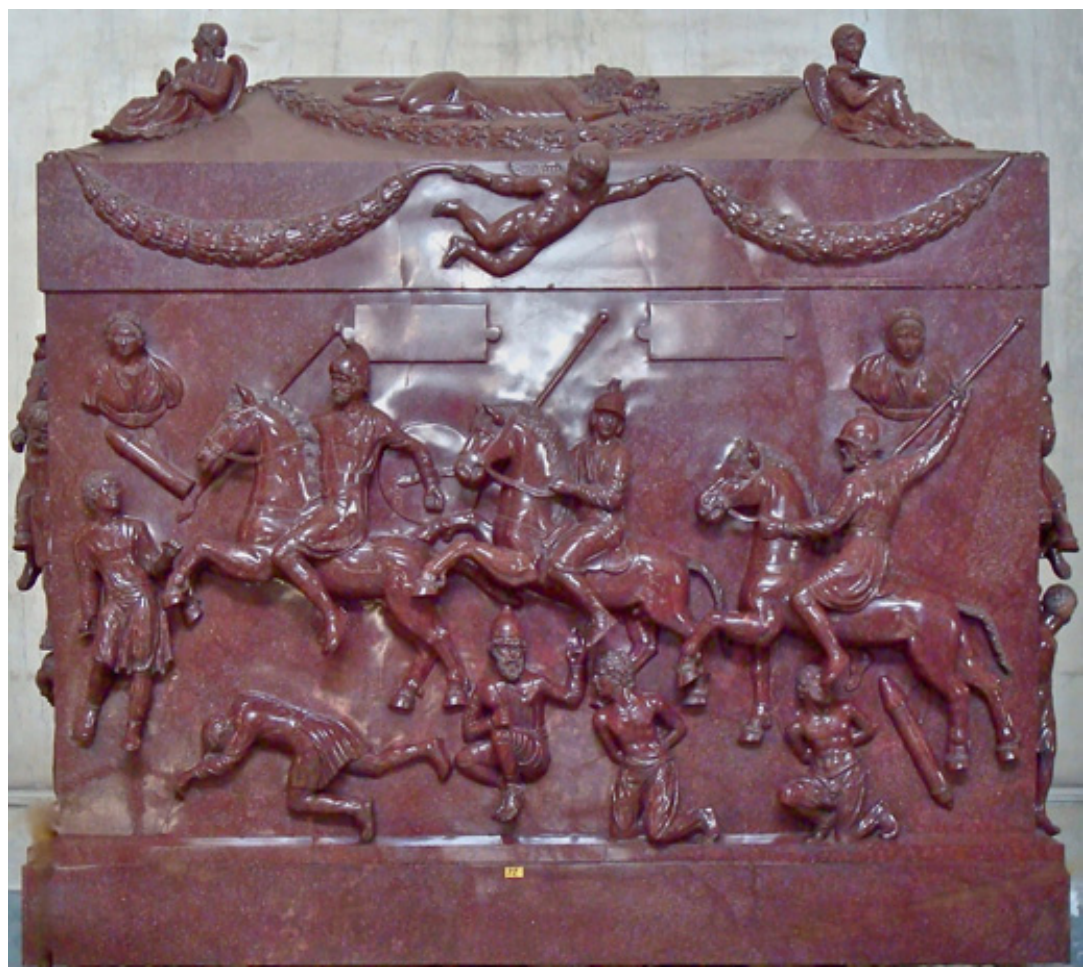

Fig. 15.5 Late Antique porphyry sarcophagus from the mausoleum of Helena, reused in 1154 for the burial of Pope Anastasius IV. In the Lateran basilica (Photo: C. Jäggi).

of Jerusalem by the Romans in AD 70 followed by the transfer of the spolia of the Jerusalem Temple to Rome. ${ }^{59}$ It is this striking accent on the Lateran in the mosaics, but also the irritating lack of a donor's inscription as well as the silence in the Liber Pontificalis concerning the construction of the portico, that led Cornelius Claussen to the intriguing assumption that it was not the pope who commissioned the portico and the design of the mosaic images, but the chapter. ${ }^{60}$ After Eugenius III (1149-54) had transformed the papal

59 The scenes from the vitae of John the Baptist and John the Evangelist also hint at the Lateran and its (secondary) patrons: Herklotz, 'Der mittelalterliche Fassadenportikus', 73-88; Claussen, 'S. Giovanni in Laterano', 79-82. See also M. Falla Castelfranchi, 'Sull'origine, e la funzione "politica”, dell'immagine del battesimo di Costantino nel portico della basilica Lateranense', in G. Bordi, I. Carlettini, M. L. Fobelli, M. R. Menna and P. Pogliani (eds.), L'officina dello sguardo: Scritti in onore di Maria Andaloro, 2 vols. (Rome, 2014), I, 375-82.

${ }^{60}$ Claussen, 'S. Giovanni in Laterano', 32 and 85-9. Cf. A. Iacobini, 'La pittura e le arti suntuarie: Da Innocenzo III al Innocenzo IV (1198-1254)', in A. M. Romanini (ed.), Roma nel Duecento: L'arte nella città dei Papi da Innocenzo III al Bonifacio VIII (Turin, 1991), 237-319, at p. 272; contra I. Herklotz, Gli eredi di Costantino: Il papato, il Laterano e la propaganda visiva nel XII secolo (La corte dei papi 6) (Rome, 2000), 218. 


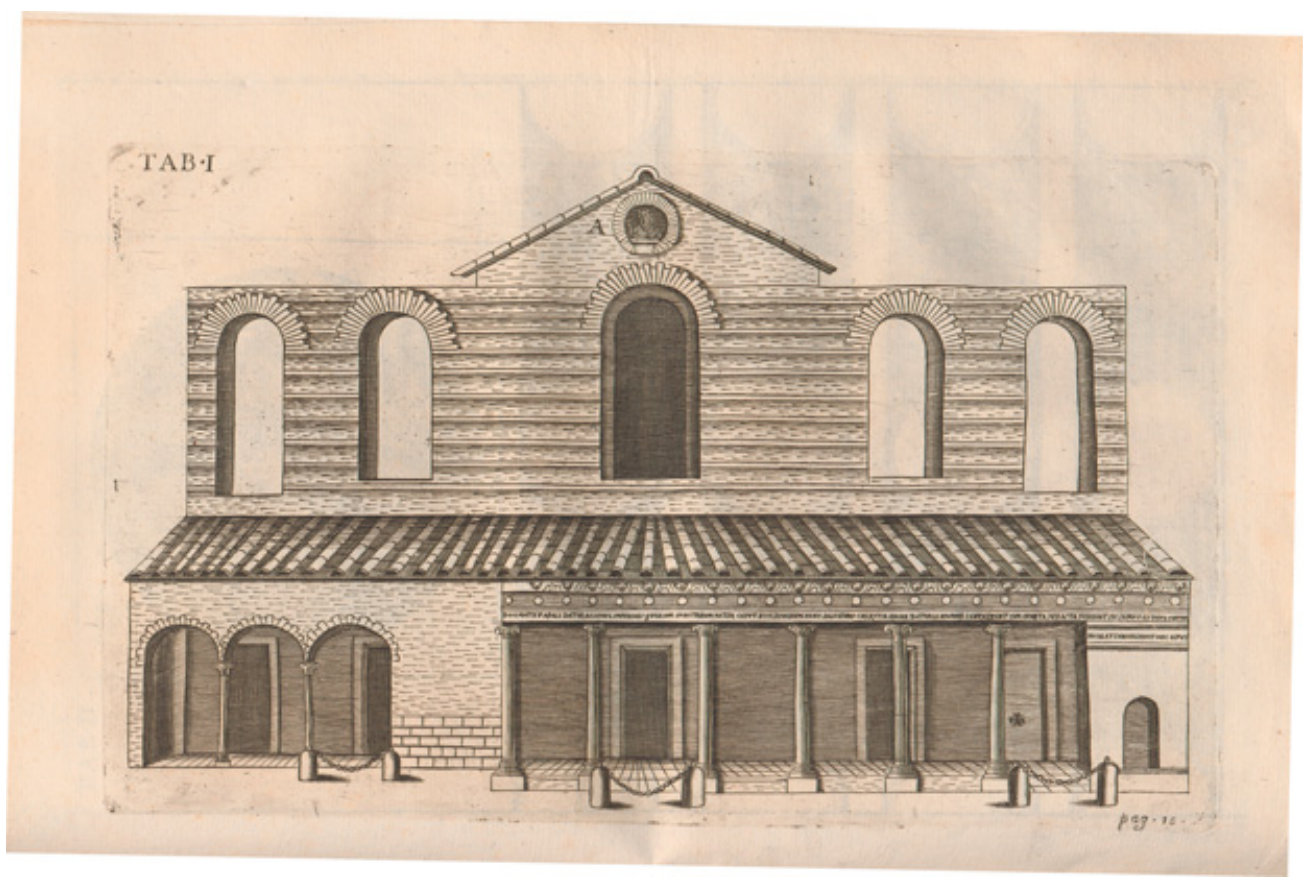

Fig. 15.6 The medieval façade of San Giovanni in Laterano with the twelfth-century portico (from Ciampini, De sacris aedificiis, table 1; ETH-Bibliothek Zürich, Rar 1279, doi.org/10.3931/e-rara-13091, Public Domain Mark).

casa at Saint Peter's into a proper palace, the popes transferred their residence more and more to the Vatican, while the old patriarchium at the Lateran lost its importance. ${ }^{61}$ In this situation, the Lateran chapter could have deliberately used the portico and its images to make the popes realise their historically founded responsibility for their cathedral. Claussen appropriately calls the mosaic programme, in which 'the legitimate home basilica (Hausbasilika) of the Roman bishop reminds one of the good old times and its proven dowry of relics', a 'courting [of the Lateran canons] for the favour of the popes who were cheating with Saint Peter's. ${ }^{62}$ This seems to

61 Steinke, Die mittelalterlichen Vatikanpaläste, 32-66; Herklotz, 'Der Campus Lateranense', 42; Monciatti, Il Palazzo Vaticano nel Medioevo, 96-182; J. Johrendt, Die Diener des Apostelfürsten: Das Kapitel von St. Peter im Vatikan (11.-13. Jahrhundert) (Berlin, 2011), 329-35.

62 Claussen, 'S. Giovanni in Laterano', 87-8: 'Es wird gleichsam eine versteckte Werbung um die Gunst der nach St. Peter "fremd gehende" Päpste sein, wenn die legitime Hausbasilika des römischen Bischofs an gute alte Zeiten und ihre bewährte Mitgift an Heiltümern erinnert. Eine derartige Botschaft ist dezent, sollte aber nachdrücklich wirken, wenn sie vom Klerus der Laterankirche dem jeweiligen Papst ausgelegt wurde und dann als Mahnung präsent bleiben sollte.' See also P. C. Claussen, 'Il XII secolo: Da Pasquale II (1099-1118) a Celestino III (1191-1198), in D’Onofrio (ed.), La committenza artistica dei papi, 275-97, at p. 294. 


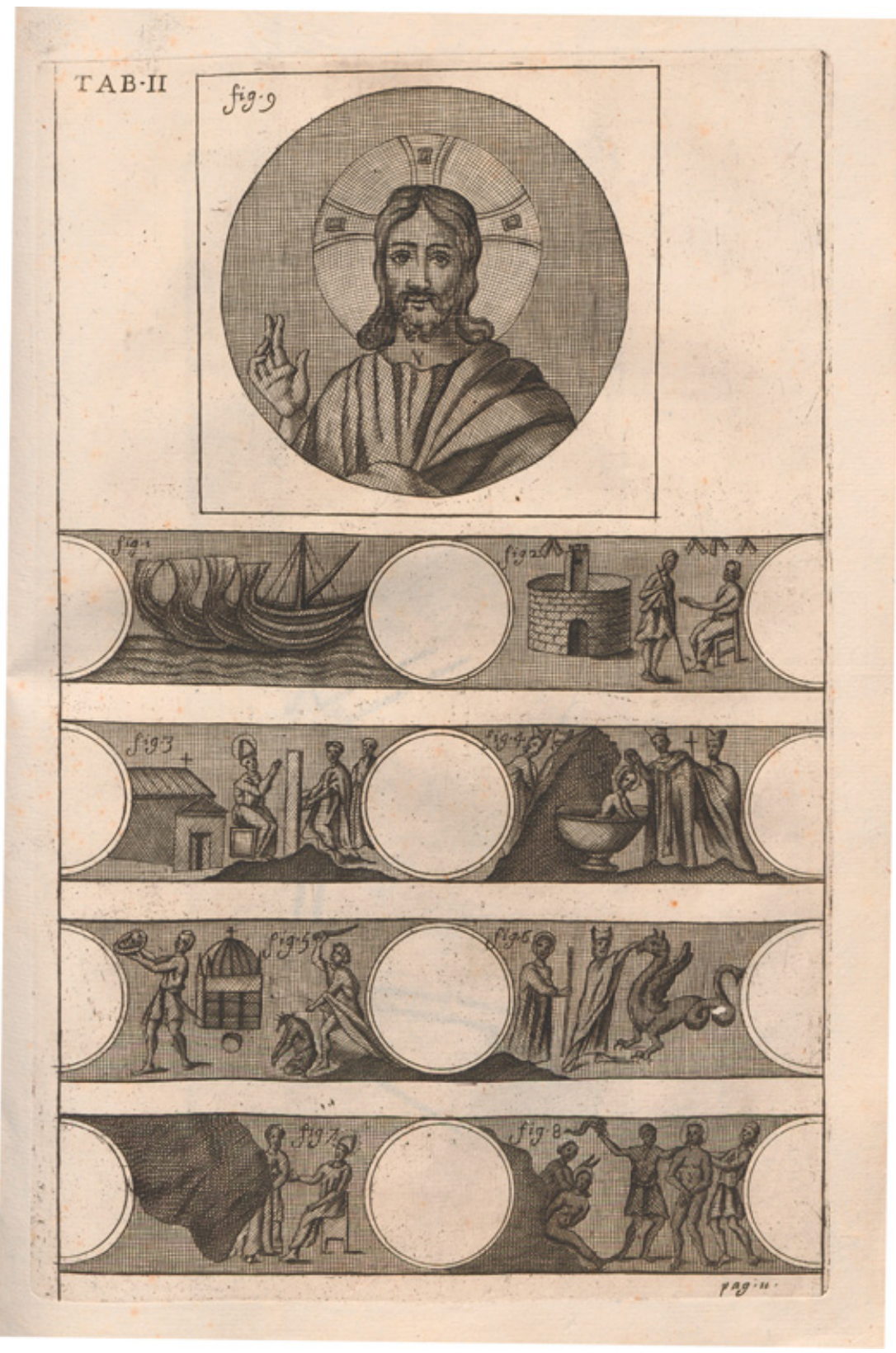

Fig. 15.7 Seventeenth-century drawings of the twelfth-century mosaics of the Lateran portico (from Ciampini, De sacris aedificiis, table 2 (detail); ETH-Bibliothek Zürich, Rar 1279, doi.org/10.3931/e-rara-13091 / Public Domain Mark). 


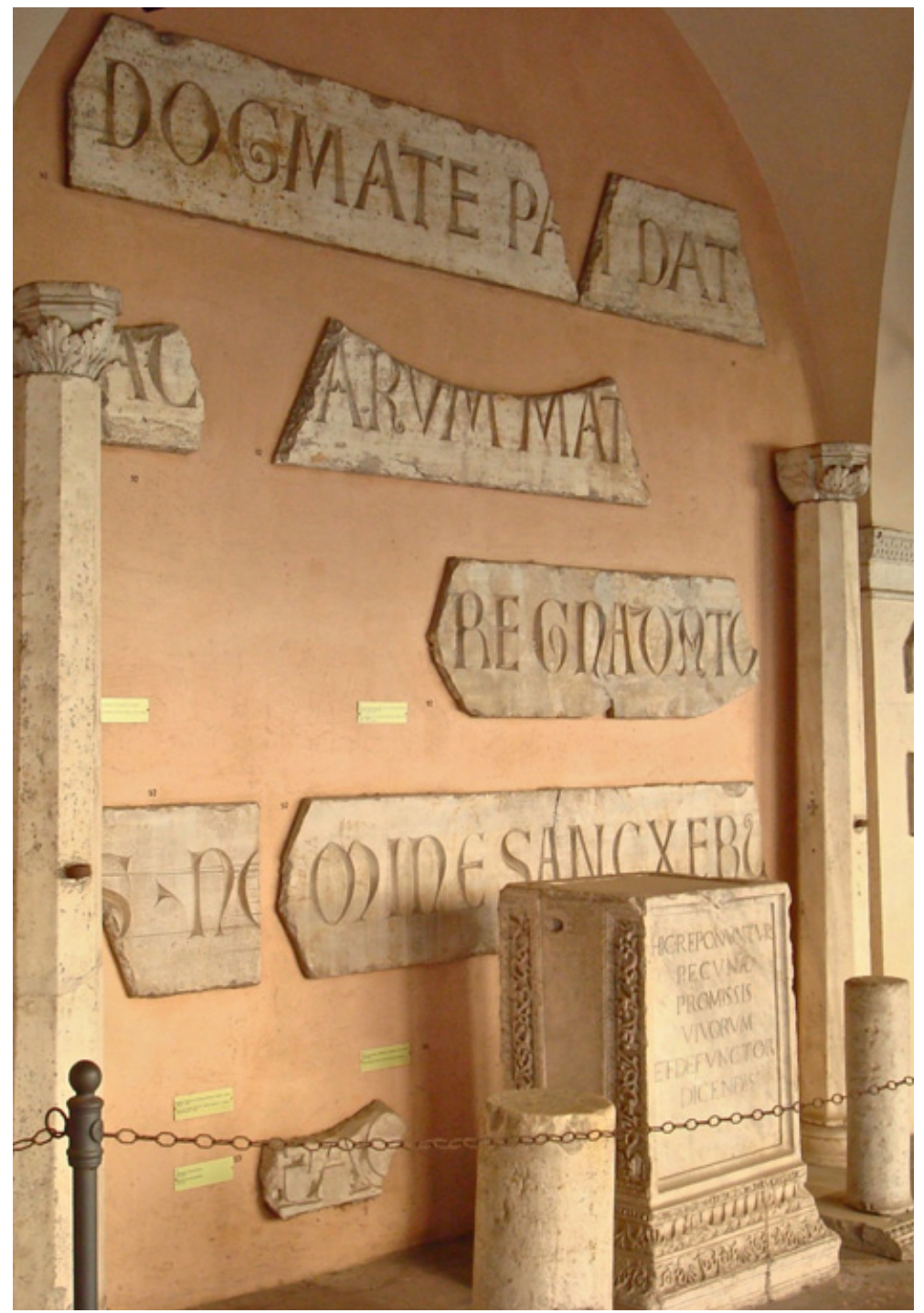

Fig. 15.8 Remaining fragments of the twelfth-century inscription of the Lateran portico, today in the cloister of San Giovanni in Laterano (Photo: C. Jäggi).

apply also to the monumental inscription on the portico (Fig. 15.8) that once again conveyed that it was the Lateran basilica that deserves to use the title 'mater et caput cunctarum ecclesiarum'. 63

63 'DOGMATE PAPALI DATUR AC SIMUL IMPERIALI/QUOD SIM CUNCTARUM MATER CAPUT ECCLESIARUM [.. .]'; for the interpretation of the inscription, see Herklotz, 'Der mittelalterliche Fassadenportikus', 89-95; Claussen, 'S. Giovanni in Laterano', 84-8. 
Only a bit later however, Saint Peter's claimed this title for itself as well; at least the inscription beneath its apse mosaic, renewed by Innocent III in the first years of the thirteenth century, speaks of it as 'mater cunctarum, decor et decus ecclesiarum'. 64 The rivalry between the old cathedral and Saint Peter's seems to have been stirred up by the chapters of the two churches. As the Lateran chapter - since its reformation in the early eleventh century - consisted of regulated Augustinian canons until its transformation into a secular canon monastery in 1299, whereas the chapter of Saint Peter's was constituted as a secular canon monastery since its foundation in the middle of the eleventh century, the two communities had different institutional backgrounds (and, based on that, perhaps a certain 'natural' antipathy). ${ }^{65}$ It is from among these two chapters that the propagandistic descriptiones of both churches emerged; they were clearly formulated interdependently at the time of Alexander III (1159-81), each with the implicit aim of stressing and justifying the primacy of its church. The author of the Descriptio Lateranensis Ecclesiae was the cathedral's canon John the Deacon; the author of the Petrinian counterpart, the Descriptio basilicae Vaticanae, was Peter Mallius, a canon of Saint Peter's. ${ }^{66}$ Yet the heading of the eleventh-century text that was used by John the Deacon as a model for his 'description' of the Lateran gives an idea of what it was all about: 'Scriptum de supremo sanctuario sanctae Dei romanae (ecclesiae)'. 67

It is interesting that the authors of the two writings primarily list the relics that were kept in their respective basilicas in order to emphasise their claims

${ }^{64}$ Herklotz, 'Der mittelalterliche Fassadenportikus', 92; A. Iacobini, 'Il mosaico absidiale di San Pietro in Vaticano', in M. Andaloro and A. Ghidoli (eds.), Fragmenta Picta: Affreschi e mosaici staccati del Medioevo romano (Rome, 1989), 119-29; A. Paravicini Bagliani, Le Chiavi e la Tiara: Immagini e simboli del papato medievale (La corte dei Papi 3) (Rome, 1998), 43-59; Johrendt, Die Diener des Apostelfürsten, 326-8; McKitterick et al., 'Introduction', 6-7; V. Pace, 'Il XIII secolo: Da Innocenzo III (1198-1216) a Bonifacio VIII (1294-1303)', in D’Onofrio (ed.), La committenza artistica dei papi, 299-329, at pp. 303-5.

65 For the history of the Lateran chapter, see T. Schmidt, 'Die Kanonikerreform in Rom und Papst Alexander II. (1061-1073), Studi Gregoriani 9 (1972), 199-221, at pp. 207-21; Blaauw, CD I, 208-13; Rehberg, Die Kanoniker, esp. 22-3; T. di Calpegna Falconieri, Il clero di Roma nel medioevo: Istituzioni e politica cittadina (secoli VIII-XIII) (Rome, 2002), 180-93; Claussen, 'S. Giovanni in Laterano', 30-4, 86-9, 255. For the early history of Saint Peter's chapter, see Johrendt, Die Diener des Apostelfürsten, 17-25.

66 Valentini and Zucchetti, Codice topografico, III, 326-73 and 382-442; for the significance of the two sources in the rivalry of the two basilicas, see III, 319-22 and 375-81; Borgolte, Petrusnachfolge und Kaiserimitation, 157-9; Herklotz, 'Der mittelalterliche Fassadenportikus', 71-2 and passim; Johrendt, Die Diener des Apostelfürsten, 316-27. For the redaction criticism of the Descriptio of John the Deacon, see C. Vogel, 'La Descriptio Ecclesiae Lateranensis du Diacre Jean: Histoire du texte manuscrit', in Mélanges en l'honneur du Monseigneur Michel Andrieu (Strasbourg, 1965), 457-76; Blaauw, CD I, 205-7.

67 D. Giorgi, De liturgia romani pontificis in solemni celebratione missarum, 3 vols. (Rome, 1744), III, 542-55; Herklotz, 'Der mittelalterliche Fassadenportikus', 71. 
to primacy. ${ }^{68}$ For the Lateran basilica, or rather for its main altar, most stress is laid - along with the mensa of the Last Supper and the five loaves and two fishes of the Feeding of the Five Thousand - on the Jewish cult objects from the Solomonic Temple in Jerusalem. ${ }^{69}$ These (and even the Ark of the Covenant) had allegedly been brought to Rome after the victory of Titus in $\mathrm{AD} 70$, and it was believed to have been Constantine who donated them to the Roman cathedral. Due to the possession of the Jewish cult objects, the Lateran basilica was henceforth qualified as the temple of the new covenant. Even columns from the Solomonic Temple are attested for the Lateran in the twelfth century, perhaps linked to the bronze Hadrianic columns reused around 1600 for the altar of the Holy Sacrament in the south transept. ${ }^{70}$ Sible de Blaauw has shown that this self-qualification of the Lateran basilica as the temple of the new covenant met a performative response in the high medieval liturgy of Maundy Thursday. As we have learned, some of the mosaics of the portico described the possession of the precious temple relics, and their transfer to Rome. ${ }^{71}$ Thus, the Roman Church had found some very clear and comprehensible arguments for its institutional claim to primacy, which in these very years (of the twelfth century) was increasingly questioned by the patriarchies of Jerusalem, Constantinople and Antioch. ${ }^{72}$

In addition to this, the argument was concerned with matters pertaining to the situation in Rome itself: arguments pro Lateran and contra Saint Peter's. So it is not surprising that the chapter of Saint Peter's in return felt compelled to not only constantly refer to the tomb of Saint Peter, but also to

68 Blaauw, CD I, 206-7. The role of relics for the enforcement of claims of power is discussed by E. Bozóky, La politique des relics de Constantin à Saint-Louis: Protection collective et légitimation du pouvoir (Paris, 2007).

69 Valentini and Zucchetti, Codice topografico, III, 83-4, 336-47, 357-8; Herklotz, 'Der mittelalterliche Fassadenportikus', 73-5 and 84-7; S. de Blaauw, 'The solitary celebration of the supreme pontiff: The Lateran basilica as the new Temple in the medieval liturgy of Maundy Thursday', in C. Caspers and M. Schneiders (eds.), Omnes circumstantes: Contributions Towards a History of the Role of the People in the Liturgy Presented to Herman Wegman (Kampen, 1990), 120-43.

70 For instance, by Benjamin of Tudela, who visited Rome and its churches in 1166: Benjamin of Tudela, The Itinerary of Benjamin of Tudela: Travels in the Middle Ages, introd. M. A. Signer (Malibu, 1992), 64; de Blaauw, 'The solitary celebration', 136 n. 67; Blaauw, CD I, 249-52. See also M.-T. Champagne, “Treasures of the Temple” and claims of authority in twelfth-century Rome', in B. M. Bolton and C. E. Meek (eds.), Aspects of Power and Authority in the Middle Ages (Turnhout, 2007), 107-18, at p. 109; D. Kinney, 'Spolia', in W. Tronzo (ed.), St Peter's in the Vatican (Cambridge, 2008), 16-47, at p. 36; A. Infrate, The Wandering Throne of Solomon: Objects and Tales of Kingship in the Medieval Mediterranean (Leiden, 2016), 38-41.

71 De Blaauw, 'The solitary celebration'; Blaauw, CD I, 233-46. See Herklotz, 'Der mittelalterliche Fassadenportikus', 46 and 74; Champagne, “"Treasures of the Temple”, 115-18. For the mosaics of the portico, see above, n. 60 .

72 Herklotz, 'Der mittelalterliche Fassadenportikus', 77-8 and 91. 
propagate 'new' relics or to revalue old objects in their possession as Petrinian or even Jesuanic contact relics. One of the best known is the Vera Icon, the sudarium of Christ, which is first attested in Saint Peter's basilica in the tenth century. ${ }^{73}$ In the Descriptio basilicae Vaticanae of Peter Mallius it is listed as an unquestionable relic of Jesus. ${ }^{74}$ In the late twelfth century it was additionally revalued by a precious ciborium commissioned by Celestine III (1191-8), and, after Innocent III had established a regular procession in 1204 , its fame reached out also into the city. ${ }^{75}$ Also the wooden throne, presumably brought to Rome by Charles the Bald on the occasion of his coronation in 875 and left to Saint Peter's, gained the status of a relic in the eleventh century, as it was considered then to be the chair of Saint Peter, the Cathedra Petri. ${ }^{76}$ From that time on the chair was also used in the ceremonial of the papal coronation. From the thirteenth century the Cathedra Petri was regularly presented as a relic to the faithful for veneration on the Feast of the Chair of Saint Peter on 22 February. In this context, the Chair was carried by the canons of Saint Peter's in a solemn procession from its depository into the church, where it was initially brought to the main altar; after mass it was placed in front of the confessio, where the faithful could approach it, venerate it and give donations.

By that time the Vatican had already won the race against the Lateran. ${ }^{77}$ Whenever the pope and the Curia stayed in Rome in the thirteenth century, they mostly resided in the palace that Innocent III had had built in the Vatican. ${ }^{78}$ This preference was finally affirmed when the popes returning from Avignon (in 1377) did not move back into the old patriarchium at the Lateran but installed themselves permanently at the Vatican. ${ }^{79}$ This does not

73 See below, n. 75. $\quad{ }^{74}$ Valentini and Zucchetti, Codice topografico, III, 411 and 420.

75 Maccarone, 'L'indulgenza', 732 and 739-40; Wolf, Salus Populi Romani, 83-4; Blaauw, CD II, 669 and 724; G. Wolf, “'Or fu sì la sembianza vostra?” Sguardi alla "vera icona” e alle sue copie artistiche', in G. Morello and G. Wolf (eds.), Il volto di Cristo (Milan, 2000), 103-14; van Dijk, 'The Veronica', 237-56.

76 Most recently, C. Jäggi, 'Cathedra Petri und Colonna Santa in St. Peter zu Rom: Überlegungen zu "Produktion” und Konjunktur von Reliquien im Mittelalter', in A. F. Bergmeier, K. Palmberger and J. E. Sanzo (eds.), Erzeugung und Zerstörung von Sakralität zwischen Antike und Mittelalter (Distant World Journal Special Issues 1) (Heidelberg, 2016), 109-31, books .ub.uni-heidelberg.de/propylaeum/catalog/book/188.

77 Maccarone, 'L'indulgenza', 736-40.

78 Steinke, Die mittelalterlichen Vatikanpaläste, 39-47; B. Schimmelpfennig, 'Der Palast als Stadtersatz: Funktionale und zeremonielle Bedeutung der Papstpaläste in Avignon und im Vatikan', in W. Paravicini (ed.), Zeremoniell und Raum (Sigmaringen, 1997), 239-56, esp. 239-44;

A. Monciatti, 'Funzione e decorazione dell'architettura nel Palazzo di Niccolò III Orsini', in T. Weddigen, S. de Blaauw and B. Kempers (eds.), Functions and Decorations: Art and Ritual at the Vatican Palace in the Middle Ages and the Renaissance (Vatican City, 2003), 27-39; V. Brancone, Le domus dei cardinali nella Roma del Duecento: Gioelli, mobili, libri (Rome, 2010), 34.

79 Luchterhandt, 'Vom Haus des Bischofs', 78-80. 
mean that the Lateran with its episcopal church now totally declined into insignificance; after all, the bull by which the primacy among the Roman churches was officially conceded to the Lateran basilica dates from 1372 that is, shortly before the return of the popes to Rome. ${ }^{80}$ The reliquaries that were commissioned by Pope Urban V in 1369-70 for the heads of the two princes of the apostles that are attested in the Lateran since the eleventh century (by then however in the papal chapel in the patriarchium) are to be seen in this context as well, as is their demonstrative exposition in the high altar ciborium. ${ }^{81}$ But by entering into the discourse about relics, and by courting pilgrims and other devout visitors by making its reliquary treasure permanently accessible and visible, just as Saint Peter's and the other pilgrimage churches did, the Lateran basilica gave up its status of exclusiveness and - as one would say today - its unique selling point. ${ }^{82}$ By the high Middle Ages the papal private chapel had been styled as a 'centre of Christian hope of salvation" ${ }^{\text {'83 }}$ that was staged between visibility and withdrawal by an intelligent management of relics. But now, in the late Middle Ages, the Lateran relics were used to openly woo the public. Since the beginning of the fourteenth century the old cathedral and its relics had been integrated into the official Roman pilgrimage route; even the old papal chapel and the relics that had remained there were now accessible for the masses of pilgrims. ${ }^{84}$ However, against the treasure of salvation that was kept in Saint Peter's, the cathedral had drawn the short straw. The lack of a saint's tomb, and hence of a person who stood as a pars pro toto for the church, could in the end not be outweighed by anything.

${ }^{80}$ See above, n. 2. Mainly in the context of the holy year 1300, we know of new elements of furnishing in the Lateran basilica initiated by members of the chapter. From 1299 onwards the chapter no longer consisted of Augustan canons, but - like the chapter of Saint Peter's - of secular canons. An especially interesting piece of this time is the so-called cross of Constantine: U. Koenen, Das 'Konstantinskreuz' im Lateran und die Rezeption frühchristlicher Genesiszyklen im 12. und 13. Jahrhundert (Worms, 1995), esp. 287-9.

81 Mondini, 'Reliquie incarnate'. See also Claussen, Die Kirchen der Stadt Rom, 190-2; Luchterhandt, 'Vom Haus des Bischofs', 77; C. Bolgia, 'Il XIV secolo: Da Benedetto XI (1303-1304) a Bonifacio IX (1389-1404)', in D'Onofrio (ed.), La committenza artistica dei papi, 331-59, at pp. 344-8.

82 Luchterhandt, 'Vom Haus des Bischofs', 84-5, rightly pointed out that the treasure in the medieval patriarchium at the Lateran was not in the possession of the pope and therefore was not taken to Avignon or to the Vatican; during the absence of the popes in Avignon in the fourteenth century, care of the papal treasure fell to the clergy of Saint Peter's.

83 Burkart, 'Die Aufhebung der Sichtbarkeit', 71.

${ }^{84}$ N. R. Miedema, Die römischen Kirchen im Spätmittelalter nach den 'Indulgentiae ecclesiarum urbis Romae' (Tübingen, 2001), 200-4; N. R. Miedema, Rompilgerführer in Spätmittelalter und Früher Neuzeit (Tübingen, 2003), 93, 159-60, 242-3; Muffel, Descrizione, 30-1. See Burkart, 'Die Aufhebung der Sichtbarkeit', 69-70; Luchterhandt, 'Vom Haus des Bischofs', 76-8. 


\section{The Basilica of Saint John Lateran to 1600}

The archbasilica of Saint John Lateran is the world's earliest cathedral. A Constantinian foundation pre-dating Saint Peter's in the Vatican, it remains the seat of the bishop of Rome, the pope, to this day. This volume brings together scholars of topography, archaeology, architecture, art history, geophysical survey and liturgy to illuminate this profoundly important building. It takes the story of the site from the early imperial period, when it was occupied by elite housing, through its use as a barracks for the emperor's horse guards to Constantine's revolutionary project and its development over 1,300 years. Richly illustrated throughout, this innovative volume includes both broad historical analysis and accessible explanations of the cutting-edge technological approaches to the site that allow us to visualise its original appearance.

LEX воSMAN is Professor of Architectural History at the University of Amsterdam, with a special interest in Early Christian and Medieval Architecture. He has been a fellow of the Royal Netherlands Institute in Rome and Scholar in Residence at the Istituto Universitario Olandese di Storia dell'Arte in Florence. He is the author of many publications, including The Power of Tradition: Spolia in the Architecture of St. Peter's in the Vatican (2004).

IAN P. HAYNES is Professor of Archaeology at Newcastle University, specialising in Roman Archaeology. He has directed twelve field projects in five countries and in 2019 was awarded an ERC Advanced Grant for a five-year investigation of SE Rome. He is the author or editor of eight books including Blood of the Provinces (2013).

PAOlo Liverani was Curator for Classical Antiquities at the Vatican Museum and is now Professor of Ancient Topography at the University of Florence. He is the author of eight books, including The Vatican Necropoleis (2010). 


\section{British School at Rome Studies}

Series editors

Barbara Borg

Chair of Publications of the British School at Rome

Rosamond McKitterick

Chair of the Faculty of Archaeology, History and Letters and member of the Council of the British School at Rome

Stephen J. Milner

Director of the British School at Rome

British School at Rome Studies builds on the prestigious and long-standing Monographs series of the British School at Rome. It publishes volumes on topics that cover the full range of the history, archaeology and art history of the western Mediterranean both by the staff of the BSR and its present and former members, and by members of the academic community engaged in top-quality research in any of these fields.

Roman Port Societies: The Evidence of Inscriptions

Edited by Pascal Arnaud and Simon Keay

Rome in the Eighth Century: A History in Art

John Osborne

Rome, Pollution and Propriety: Dirt, Disease and Hygiene in the Eternal City from Antiquity to Modernity

Edited by Mark Bradley, with Kenneth Stow

Old Saint Peter's, Rome

Edited by Rosamond Mckitterick, John Osborne, Carol M. Richardson and Joanna Story

The Punic Mediterranean: Identities and Identification from Phoenician Settlement to Roman Rule

Edited by Josephine Crawley Quinn and Nicholas C. Vella

Turin and the British in the Age of the Grand Tour

Edited by Paola Bianchi and Karin Wolfe 


\section{The Basilica of Saint John Lateran to 1600}

Edited by

L. BOSMAN

Universiteit van Amsterdam

I. P. HAYNES

Newcastle University

P. LIVERANI

Università degli Studi di Firenze

\section{国图 CAMBRIDGE \\ 包) UNIVERSITY PRESS}




\section{CAMBRIDGE \\ UNIVERSITY PRESS}

University Printing House, Cambridge CB2 8BS, United Kingdom

One Liberty Plaza, 20th Floor, New York, NY 10006, USA

477 Williamstown Road, Port Melbourne, VIC 3207, Australia

314-321, 3rd Floor, Plot 3, Splendor Forum, Jasola District Centre,

New Delhi - 110025, India

79 Anson Road, \#06-04/06, Singapore 079906

Cambridge University Press is part of the University of Cambridge.

It furthers the University's mission by disseminating knowledge in the pursuit of education, learning, and research at the highest international levels of excellence.

www.cambridge.org

Information on this title: www.cambridge.org/9781108839761

DOI: $10.1017 / 9781108885096$

(C) The British School at Rome 2020

This publication is in copyright. Subject to statutory exception and to the provisions of relevant collective licensing agreements, no reproduction of any part may take place without the written permission of Cambridge University Press.

First published 2020

Printed in the United Kingdom by TJ International Ltd, Padstow Cornwall

A catalogue record for this publication is available from the British Library.

Library of Congress Cataloging-in-Publication Data

Names: Bosman, Lex, editor. | Haynes, Ian P., editor. | Liverani, Paolo, editor. | Lateran

Basilica (Conference) (2016 : British School at Rome)

Title: The Basilica of Saint John Lateran to 1600 / edited by L. Bosman, Universiteit van Amsterdam; I.P. Haynes, University of Newcastle upon Tyne; P. Liverani, Università degli Studi di Firenze, Italy.

Description: Cambridge ; New York : Cambridge University Press, 2020. | Series: British School at Rome studies | Includes bibliographical references and index.

Identifiers: LCCN 2020004191 (print) | LCCN 2020004192 (ebook) | ISBN 9781108839761 (hardback) | ISBN 9781108885096 (ebook)

Subjects: LCSH: Basilica di S. Giovanni in Laterano - History - Congresses. | Basilicas Italy - Rome - History - Congresses. | Caelian Hill (Italy) - History - Congresses. | Rome (Italy) - Buildings, structures, etc. - Congresses.

Classification: LCC NA5620.S4 B37 2020 (print) | LCC NA5620.S4 (ebook) | DDC $720.9456 / 32-\mathrm{dc} 23$

LC record available at https://lccn.loc.gov/2020004191

LC ebook record available at https://lccn.loc.gov/2020004192

ISBN 978-1-108-83976-1 Hardback

Cambridge University Press has no responsibility for the persistence or accuracy of URLs for external or third-party internet websites referred to in this publication and does not guarantee that any content on such websites is, or will remain, accurate or appropriate. 


\section{Contents}

List of Figures [page viii]

List of Contributors [xxiv]

Acknowledgements [xxv]

List of Abbreviations [xxvii]

1 The Lateran Basilica to 1600 [1]

IAN P. HAYNES, PAOLO LIVERANI AND LEX BOSMAN

2 The Evolution of the Lateran: From the Domus to the Episcopal Complex [6]

PAOLO LIVERANI

3 At the Foot of the Lateran Hill, from Via Sannio to Viale Ipponio: Archaeological Investigations Prior to the Construction of Metro Line C [25]

ROSSELLA REA AND NICOLETTA SAVIANE

4 Ground-Penetrating Radar Survey in the Saint John

Lateran Basilica Complex [52]

SALVATORE PIRO, IAN P. HAYNES, PAOLO LIVERANI

AND DANIELA ZAMUNER

5 The First Residential Phases of the Lateran Area and a Hypothesis to Explain the So-Called Trapezoidal

Building [71]

GIANDOMENICO SPINOLA

6 The Castra Nova and the Severan Transformation of

Rome [91]

IAN P. HAYNES AND PAOLO LIVERANI

7 Andrea Busiri Vici and the Excavations of 1876:

A Reassessment of the Archaeological Evidence [114] SABINA FRANCINI

8 Visualising the Constantinian Basilica [134]

LEX BOSMAN, PAOLO LIVERANI, IWAN PEVERETT

AND IAN P. HAYNES 
9 Constantine's Spolia: A Set of Columns for San Giovanni in Laterano and the Arch of Constantine in Rome [168] LEX BOSMAN

10 The Constantinian Basilica in the Early Medieval Liber Pontificalis [197] ROSAMOND MCKITTERICK

11 The Lateran Baptistery in the Fourth and Fifth Centuries: New Certainties and Unresolved Questions [221] OLOF BRANDT

12 The Nymphaeum of Pope Hilarus [239] PAOLO LIVERANI AND IAN P. HAYNES

13 Examples of Medieval Construction Techniques in the Basilica of San Giovanni in Laterano [250] LIA BARELLI

14 The Medieval Portico of Saint John Lateran [276] ANNA MARIA DE STROBEL AND NICOLETTA BERNACCHIO

15 MATER ET CAPUT OMNIUM ECCLESIARUM: Visual Strategies in the Rivalry between San Giovanni in Laterano and San Pietro in Vaticano [294] CAROLA JÄGGI

16 The Remodelling of San Giovanni in Laterano by Pope Nicholas IV: Transept, Apse and Façade [318] PETER CORNELIUS CLAUSSEN

17 Furtum Sacrilegum: The 'Holy Heads' of Peter and Paul and Their Reliquaries in the Lateran [345] DANIELA MONDINI

18 Reconsidering the Traces of Gentile da Fabriano and Pisanello in the Lateran Basilica [379] ANDREA DE MARCHI

19 The Rite of the Reconciliation of Penitents at the Lateran Basilica [400] JOHN F. ROMANO

20 The New Passion Relics at the Lateran, Fifteenth to Sixteenth Centuries: A Translocated Sacred Topography [428] NADJA HORSCH 
21 The East Façade of the Complex of Saint John Lateran in the Modern Era [466]

ALESSANDRO IP POLITI

22 The Book of Acts in the Constantinian Basilica: Cardinal Cesare Baronio and the Navata Clementina in San

Giovanni in Laterano [492]

FILIP MALESEVIC

Bibliography [523]

Index [572] 